\title{
LEY DE PROTECCION A TESTIGOS Y PERITOS
}

\author{
José Ricardo Palacio Sánchez-Izquierdo
}

\section{Introducción}

El día 23 de diciembre de 1994 se aprobaba la «Ley Orgánica de Protección a Testigos y Peritos en causas criminales», publicada en el Boletín Oficial del Estado de fecha 24 de diciembre de 1994. Con ello culminaba un largo proceso legislativo iniciado por el Grupo Parlamentario de Senadores Nacionalistas Vascos con su presentación ante la Alta Cámara de una Proposición de Ley «de protección a denunciantes, testigos y peritos en determinadas causas criminales» 1 .

En una primera aproximación al tema cabría calificar a la nueva Ley de necesaria, difícil y polémica.

Necesaria por cuanto el deber de cooperar con la Administración de Justicia en los procesos penales en calidad de testigo o perito (art. 118 de la Constitución Española; art. 17 de la Ley Orgánica del Poder Judicial y arts. 410, 420, 462 y 463 de la Ley de Enjuiciamiento Criminal) debía tener como contrapartida la obligación por parte del Estado de brindar protección a dichos colaboradores cuando el prestar auxilio a la justicia supusiese un riesgo grave para sí mismos o para sus más próximos allegados; piénsese, por ejemplo, en procesos contra la delincuencia violenta organizada ${ }^{2}$. Las

1 El texto de dicha Proposición apareció publicado en el Boletín Oficial de las Cortes Generales (Senado), de fecha 15 de septiembre de 1993.

2 El Juez Garzón, a raíz de la sentencia dictada en la causa «Operación Nécora» hizo unas declaraciones públicas en las que manifestaba tener conocimiento de la muerte en extrañas circunstancias de doce personas que habían colaborado con la Administración de Justicia en procesos penales incoados contra narcotraficantes.

Tratándose de causas contra terroristas los testigos y peritos no necesitan siquiera ser explícitamente amenazados para que desvíen su declaración o informe: se sienten ya víctimas en potencia por el mero hecho de cumplir con su deber. 
previsiones contenidas al respecto en el art. 325.bis del Código Penal eran de todo punto insuficientes.

Difícil, ya que una Ley de esta naturaleza ha de conseguir un punto de equilibrio, altamente inestable, entre los derechos fundamentales de testigos y peritos (vida, integridad, libertad, seguridad, etc.) y el derecho del reo a un juicio con todas las garantías (art. 24 de la Constitución Española).

Y polémica, toda vez que alguna de las previsiones de la nueva Ley (en particular ciertos aspectos de la regulación de la prueba en el acto del juicio oral) podría suscitar dudas de anticonstitucionalidad, no tanto por el texto en sí mismo cuanto por la aplicación que de él pudieran hacer los Tribunales.

En suma, la nueva Ley de Protección de Testigos no es una panacea universal, como más adelante se pondrá de relieve al hacer el estudio crítico de su articulado; podrá tener luces y sombras; exigirá un cuidado exquisito en su aplicación pero, en todo caso, constituía un imperativo si se desea luchar eficazmente contra las manifestaciones más graves de la criminalidad $^{3}$.

\section{Precedentes legislativos en el derecho comparado}

La Ley de referencia, con ser materia virgen en el Estado Español, no carece sin embargo de precedentes en el derecho comparado, en las resoluciones del Tribunal Europeo de Derechos Humanos y en la Jurisprudencia del Tribunal Constitucional de este país. Precedentes fácilmente detectables a lo largo de su articulado.

Así, en Estados Unidos, el Fiscal General puede proporcionar una nueva residencia y otros tipos de protección a un testigo o a un testigo potencial del Gobierno Federal o de un Gobierno Estatal, en un procedimiento oficial relacionado con una actividad criminal organizada o con otro tipo de delito grave, si el Fiscal General estima que es posible que se cometa un delito que implique un crimen de violencia contra el testigo relacionado con dicho procedimiento, o un delito Estatal que sea similar en naturaleza a cualquiera de dichos delitos.

El Fiscal General también puede proporcionar una nueva residencia y otros tipos de protección a la familia directa, o a una persona directa-

3 Palacio SÁnchez-IzQuierdo, José RicARdo. «Nueva delincuencia: aspectos problemáticos de la gran reforma penal». Cuadernos de Derecho Judicial. La nueva delincuencia. Tomo I. Consejo General del Poder Judicial. Madrid, 1993, pp. 19 y siguientes.

Consúltese también la Monografía de Giménez García, JoAQuín. «El testigo y el perito. Su protección en el juicio oral». Revista Actualidad Penal n. ${ }^{\circ} 40$. 
mente relacionada con dicho testigo o con dicho testigo potencial, si la familia o la persona pudiera estar en peligro por la participación del testigo en el proceso judicial.

En relación con la protección de un testigo, o de un testigo potencial, o de un miembro de la familia directa o de una persona relacionada directamente con el testigo o con el testigo potencial, el Fiscal General emprenderá las acciones que considere necesarias para proteger a la persona involucrada ante posibles lesiones físicas y para asegurar la salud, seguridad y bienestar de dicha persona, incluyendo el bienestar psicológico y el ajuste social de dicha persona, en tanto en cuanto exista peligro para dicha persona de acuerdo con los criterios del Fiscal General.

Concretamente, el Fiscal General puede:

a) Proporcionar los documentos adecuados para dar a la persona una nueva identidad o para proteger a la persona de alguna otra manera.

b) Proporcionar alojamiento a la persona.

c) Proporcionar el transporte del mobiliario doméstico y otras propiedades personales a la nueva residencia de la persona.

d) Proporcionar a la persona un sueldo para cubrir los gastos básicos.

e) Ayudar a la persona a encontrar empleo.

f) Proporcionar otros servicios necesarios para ayudar a la persona a ser autosuficiente.

g) Revelar o negarse a revelar la identidad o localización de la persona reubicada o protegida, después de sopesar el peligro que supondría para la persona dicha revelación, el detrimento que causaría a la efectividad general del programa, y el beneficio que aportaría al público o a la persona que precisa la información, con la excepción de que el Fiscal General, a petición de los Agentes locales o estatales o mediante una orden del Tribunal, deberá revelar a dichos Agentes la identidad, ubicación, archivos criminales y huellas dactilares de la persona reubicada o protegida, cuando el Fiscal General sepa, o la petición indique, que la persona está bajo investigación, o ha estado arrestada o acusada de un delito castigado con más de un año de cárcel, o sea un crimen de violencia.

h) Dispensará la obtención de servicios, materiales y suministros y la renovación y construcción de lugares seguros de los edificios existentes según otras disposiciones legales tal y como se precise para mantener la seguridad de los testigos protegidos y la integridad del programa de seguridad de testigos. 
El Fiscal General establecerá un sistema de archivos preciso, eficaz y efectivo, relacionado con el historial criminal de las personas a las que se ha proporcionado protección según este capítulo.

Antes de proporcionar protección a cualquier persona, el Fiscal General obtendrá información relacionada con la conveniencia de la persona para la inclusión en el programa, incluyendo el historial criminal, si lo hay, y un examen psicológico de la persona. El Fiscal General también efectuará un examen escrito en cada caso de la seriedad de la investigación o del caso en el que se haya proporcionado o se proporcionará la información o el testimonio de la persona y del posible riesgo de peligro para otras personas y propiedades de la comunidad donde se supone que se va a reubicar a la persona y determinará si la necesidad del testimonio de dicha persona supera el riesgo de peligro para el público.

A la hora de evaluar si se debe proporcionar protección a una persona el Fiscal General considerará el archivo criminal de la misma, otras alternativas para proporcionar protección, la posibilidad de asegurar un testimonio similar con otras fuentes, la necesidad de proteger a la persona, la importancia relativa del testimonio de dicha persona, los resultados de los exámenes psicológicos, si proporcionar dicha protección irrumpirá de forma sustancial en la relación entre un niño que tendría que cambiar de residencia con motivo de dicha protección, y los padres del niño que pudieran no reubicarse, y otros factores similares que considere apropiados el Fiscal General.

El Fiscal General no proporcionará protección a ninguna persona si el riesgo de peligro para el público, incluyendo el daño potencial a víctimas inocentes, sobrepasa la necesidad del testimonio de dicha persona.

Antes de proporcionar protección a cualquier persona, el Fiscal General tomará parte en un «memorándum de acuerdo» con dicha persona. Cada «memorándum de acuerdo» establecerá las responsabilidades de esa persona, incluyendo:

a) El acuerdo de esa persona, siendo un testigo o un testigo potencial, para testificar y proporcionar información.

b) El acuerdo de no cometer ningún delito.

c) El acuerdo de la persona a tomar todas las medidas necesarias para evitar averiguaciones debidas a otros factores relacionados con la protección proporcionada.

d) El acuerdo de la persona para cumplir con las obligaciones legales y sentencias civiles contra la misma.

e) El acuerdo a cooperar en todas las peticiones razonables de los oficiales y empleados del Gobierno que le estén proporcionando protección. 
f) El acuerdo para designar a otra persona que actúe como Agente en la presentación del proceso.

g) El acuerdo a efectuar una declaración jurada de todas las obligaciones legales principales, incluyendo las obligaciones relacionadas con la custodia y visita de los niños.

h) El acuerdo de revelar cualquiera de las obligaciones de la libertad condicional o de la libertad vigilada, y si la persona está en libertad condicional o libertad vigilada de conformidad con la ley estatal, a consentir la vigilancia federal.

i) El acuerdo de informar regularmente al oficial del programa de las actividades y de la dirección actual de dicha persona.

Si el Fiscal General determina que el daño para una persona a la que se ha proporcionado protección es inminente o que el no proporcionar una protección inmediata pondría en peligro la investigación, el Fiscal General puede proporcionar una protección temporal inmediata a dicha persona.

El Fiscal General puede finalizar la protección proporcionada a cualquier persona que quebrante el «memorándum de acuerdo» realizado entre el Fiscal General y la persona.

Un Comité nombrado «ad hoc» ha concluido que 12 años de experiencia en el tema de la protección de testigos de acuerdo con el acta de 1970 han probado, ampliamente, tanto la necesidad como la utilidad de dichas disposiciones.

En Italia, por Decreto Ley de 15 de enero de 1991 se adoptaron una serie de medidas dirigidas a la protección de testigos que colaboran con la Administración de Justicia. Se transcriben a continuación los artículos más importantes de dicha disposición legislativa.

\section{Artículo 9:}

Primero.-Con respecto a las personas expuestas a peligro grave y real por efecto de su colaboración o de las declaraciones realizadas en el curso de las investigaciones preliminares o del juicio, en referencia a los delitos previstos en el art. 380 del Código Penal, se pueden adoptar medidas de protección aptas a asegurar su incolumidad, suministrando, cuando sea necesario, la asistencia prevista en las disposiciones del presente capítulo.

Segundo.-Dichas medidas se pueden adoptar también con respecto a los allegados más próximos, los convivientes y las personas que estén expuestas a peligro grave y real a causa de las relaciones que mantienen con las personas indicadas en el anterior apartado primero.

\section{Artículo 10:}

Primero.-Según lo previsto por las normas ya en vigor, en los casos en que las medidas de protección que puedan ser adoptadas directamente 
por el Comisario para la coordinación de la lucha contra la delincuencia de tipo mafioso, por la autoridad de seguridad pública o, si se trata de una persona detenida, por el Ministerio de Justicia — Departamento de Administración Penitenciaria-, no se consideran adecuadas para asegurar la incolumidad de los sujetos implicados en el art. 9 y el peligro se derive de los elementos que los mismos sujetos aportaren o puedan aportar a las investigaciones o al juicio, se puede definir un programa especial de protección que comprenda, si fuera necesario, también medidas de asistencia.

Segundo.-Con Decreto del Ministerio del Interior, de acuerdo con el Ministerio de Justicia, después de oír la opinión de los Ministros interesados, se constituye una Comisión Central para la definición y aplicación del programa especial de protección, compuesta por un Subsecretario de Estado que la preside, por dos Magistrados con particular experiencia en procesos por hechos de criminalidad organizada y por cinco funcionarios y oficiales expertos en el sector. Para las tareas de secretaría, la Comisión Central utiliza la Oficina para la Coordinación y la Planificación de las Fuerzas de Policía.

Tercero.-Las medidas de protección y asistencia en favor de las personas admitidas al programa especial previsto en el apartado 1), así como los criterios de formulación del programa mismo y las modalidades de actuación, se establecen por decreto del Ministro del Interior, de acuerdo con el Ministro de Justicia, después de oír las opiniones del Comité Nacional de Orden y Seguridad Pública y de la comisión central prevista en el apartado 2).

\section{Artículo 11:}

Primero.-La admisión al programa especial de protección, los contenidos y la duración del mismo, valorados en relación con el riesgo para la incolumidad del sujeto a causa de las declaraciones que ha prestado o que puede prestar, los delibera la Comisión prevista en el art. 10, bajo propuesta motivada del Fiscal del Estado o bien, previo parecer favorable de este mismo, por el alto Comisario para la coordinación de la lucha contra la delincuencia de tipo mafioso o por el Gobernador Civil. En casos de urgencia especial, las medidas necesarias son adoptadas por el Jefe de Policía — Director General de la Seguridad Pública—, quien informa al Ministro.

Segundo. - La propuesta debe contener las noticias y los elementos referentes a la gravedad y actualidad del peligro al que las personas están o pueden estar expuestas por efecto de su elección de colaborar con la Justicia. Asimismo, en la propuesta se deben indicar las eventuales medidas de protección ya adoptadas y los motivos por los cuales las mismas no se consideran adecuadas a las exigencias.

Tercero.-La opinión del Fiscal del Estado debe hacer referencia específica a la importancia de la contribución ofrecida o que pueda ser ofrecida por el interesado o por su allegado para el desarrollo de las investigaciones o para el juicio penal. 


\section{Artículo 12:}

Primero.-Las personas con respecto a las cuales se ha presentado la propuesta de admisión al programa especial de protección deben expedir a la autoridad que la propone una declaración completa y documentada referente a su estado civil, de familia y patrimonial, las obligaciones que se deriven de la Ley, de pronunciamiento de la autoridad o de negocios jurídicos, los procedimientos penales, civiles y administrativos pendientes, los títulos de estudio y profesionales, las autorizaciones, las licencias, las concesiones y cualquier otro título del que sean titulares. Dichas personas deben así mismo designar un representante general o representantes especiales para las actas a realizar.

Segundo.-El programa especial de protección está suscrito por los interesados, quienes se comprometen personalmente a:

A) Observar las normas de seguridad prescritas y colaborar activamente en la ejecución del programa.

B) Cumplir las obligaciones previstas por la Ley y las obligaciones contraídas.

\section{Artículo 13:}

Primero.-El programa especial de protección puede comprender el traslado de las personas indicadas en el art. 9 a Ayuntamientos distintos del de residencia o a lugares protegidos así como las medidas necesarias para garantizar la discreción.

Segundo.-Unicamente para los fines previstos en el apartado primero puede ser autorizada la utilización temporal de un documento de cobertura. La utilización de dicho documento en casos no autorizados será castigado según las disposiciones penales vigentes.

Tercero.-Cuando existan particulares motivos de seguridad, el Fiscal del Estado o el Juez pueden autorizar al sujeto examinado o interrogado a elegir domiciliarse en casa de una persona de su confianza o en una Comisaría de Policía, también para las comunicaciones o notificaciones que sean necesarias.

Cuarto.-Por motivos de seguridad graves y urgentes, el Fiscal del Estado puede autorizar a la Policía Judicial a custodiar a las personas arrestadas o detenidas en lugares distintos a la cárcel durante el tiempo estrictamente necesario para definir el programa especial de protección. Por las mismas razones, la autorización puede ser dictada por el Juez cuando estime necesario aplicar la custodia cautelar.

\section{Artículo 15:}

Primero.-En el ámbito del programa especial de protección, cuando cualquier otra medida resulte inadecuada, por decreto del Ministro del Interior, de acuerdo con el Ministro de Justicia, se puede autorizar, a petición de los interesados, el cambio de los datos personales garantizando su discreción también en los actos de la Administración Pública. 
También Alemania cuenta con disposiciones legales protectoras de testigos en causas relacionadas con el terrorismo ${ }^{4}$.

Particular atención merece el caso de Holanda, país en el cual la Ley de Enjuiciamiento Criminal no recoge explícitamente la declaración de testigos anónimos. Sin embargo, ante el incremento de la delincuencia violenta y organizada, se sintió la necesidad — basada en la protección contra represalias - de asegurar el anonimato de ciertos testigos en determinadas causas criminales.

En 1983 la Asociación de Magistrados expresó su preocupación ante el aumento del número de asuntos en los cuales los testigos se encontraban amenazados, por lo que se negaban a declarar si no se les aseguraba su anonimato, y recomendaba al Legislador impulsar el tema de los testigos anónimos.

En consecuencia, el Ministerio de Justicia instituyó en el año 1984 una comisión consultiva, denominada «Comisión sobre los testigos amenazados», encargada de estudiar este problema ${ }^{5}$.

El día 11 de junio de 1985, la citada comisión presentaba al Ministro un bien documentado dictamen que concluía con el borrador de un Proyecto de Ley del siguiente tenor:

\section{Artículo 1:}

En el Código de Enjuiciamiento Criminal se introducen las siguientes modificaciones:

a) En el apartado 67, apartado primero, al comienzo y en el epígrafe b) se añade después de 285 , apartado primero: 285 -A.

b) Después del art. 187 se añade un nuevo artículo con el siguiente texto:

\section{Artículo 187-A:}

Primero.- Si se produjera el caso previsto en el art. 190, apartado segundo, se tomará declaración al testigo de forma que su identidad permanezca en secreto. El Juez Instructor cuidará de que el testigo sea protegido de un eventual reconocimiento con ocasión de la prestación de su declaración.

Segundo.—El Juez Instructor puede ordenar, en caso necesario, que el sospechoso y su Abogado no presencien el interrogatorio del testigo, en cuyo caso el Fiscal tampoco estará presente. El Juez Instructor les infor-

${ }^{4}$ Ley de 9 de junio de 1989.

${ }^{5}$ Es de significar que, aun sin expresa regulación legal, el Tribunal de casación holandés había permitido, en ciertos casos, el anonimato de los testigos (sentencias de 17 de enero de 1938; 5 de febrero de 1980; 4 de mayo de 1981 y 29 de noviembre de 1983). Sin embargo, las sentencias posteriores al «caso Kostovski», que llegó al Tribunal Europeo de Derechos Humanos, y a la que luego se hará referencia, han introducido algunas modificaciones (véanse sentencias del tribunal de casación de fecha 25 septiembre 1984 y 21 mayo 1985). 
mará, en la medida de lo posible, del contenido de las declaraciones efectuadas por el testigo, ofreciéndoles la posibilidad de hacer constar las preguntas que deseen le sean planteadas. A menos que el interés de la investigación no permita ningún retraso en el interrogatorio, se podrán presentar las preguntas ya antes de su inicio.

c) Delante del texto del art. 190 se sitúa un número primero y a este artículo se le añaden los siguientes apartados:

Segundo.-El Juez Instructor puede, con el fin de mantener en secreto la identidad del testigo, decidir de oficio, a instancia del Fiscal o a petición del sospechoso o de un Abogado o del propio testigo, no preguntar al testigo acerca de los datos mencionados en el apartado primero. El Fiscal y el sospechoso y su Abogado tendrán la posibilidad de ser escuchados a este respecto.

Tercero.-La decisión del Juez Instructor será comunicada inmediatamente al Fiscal y al Abogado, así como notificada al sospechoso.

Cuarto.-Si el Juez Instructor resolviera denegando, no procederá al interrogatorio del testigo antes de que su decisión sea firme.

Quinto.-El Fiscal y el sospechoso pueden interponer recurso contra la decisión ante el Tribunal en el plazo de tres días. Si el Tribunal considera fundado el recurso presentado contra una decisión adoptada de acuerdo con lo dispuesto en el apartado segundo, declarará, puesto que el Juez Instructor ya habrá interrogado al testigo en la forma descrita en tal apartado, que la declaración del testigo debe ser calificada como no realizada para la prueba de acusación. Si el Tribunal considera fundado el recurso presentado contra una decisión adoptada de acuerdo con lo dispuesto en el apartado cuarto, ordenará que se practique aun el interrogatorio del testigo teniendo en cuenta el art. 187-A.

Sexto.-Contra la resolución del Tribunal no cabe recurso de casación.

Séptimo.-La decisión a que hace referencia el apartado segundo sólo podrá adoptarse si el testigo u otra persona pudiera considerarse amenazada de tal forma en razón de la declaración que va a prestar, que se deba suponer razonablemente que peligra seriamente su vida, su salud o su posición social, y si el testigo hubiere dado a conocer que debido a tales amenazas no prestaría declaración de otro modo.

b) Tras el art. 190 se añade un nuevo artículo con el siguiente texto:

\section{Artículo 190-A:}

El Juez Instructor, cuando estime que el testigo pueda sufrir fuerza mayor en relación con la prestación de su declaración o verse obstaculizado en el ejercicio de su función, puede prescindir de la formalidad de preguntarle por su nombre, domicilio o residencia.

e) Delante del art. 218 se sitúa un número primero, añadiéndose al artículo el siguiente apartado:

Segundo.-Lo dispuesto en el apartado primero será de análoga aplicación a los funcionarios judiciales y a las demás personas implicadas 
tanto en el interrogatorio de testigos efectuado ante el Juez Instructor en la forma establecida en el art. 187-A, como en un interrogatorio previo realizado durante la investigación preliminar.

f) Después del art. 263 se añade un nuevo artículo con el siguiente texto:

\section{Artículo 264:}

El Fiscal puede, además, mediante decisión motivada, denegar la citación o el llamamiento de un testigo:

A) Si éste ya ha sido oído en la forma prevista en el art. 187-A o,

B) Cuando éste no haya sido oído por el Juez Instructor, si se halla, a juicio del Fiscal, en las circunstancias mencionadas en el art. 190, apartado séptimo, letra A.

g) En el art. 280 se añade en los apartados tercero y cuarto entre las palabras «omitido o» y «rechazado»: en base al art. 263, apartado cuatro.

Así mismo se añade al apartado cuarto una nueva frase con el siguiente texto: El Tribunal, cuando no excluya en el caso del art. 264 párrafo B, la posibilidad de que existan amenazas en el sentido del art. 190, apartado séptimo, suspenderá las actuaciones y remitirá la causa al Juez Instructor, con el fin de que interrogue al testigo en la forma prevista en los arts. 1.87-A y 216.

h) En el art. 284, apartado primero, se añade: cuando el Tribunal estime que el testigo puede sufrir fuerza mayor en relación con la prestación de una declaración o verse obstaculizado en el ejercicio de su función, el Presidente podrá prescindir de la formalidad de preguntarle por su nombre, domicilio o residencia.

i) $\mathrm{Al}$ art. 315 se le añade un segundo apartado con el siguiente texto:

Segundo.-Lo dispuesto en la última frase del apartado cuarto del art. 280 con respecto al testigo amenazado es de aplicación análoga.

j) $\mathrm{Al}$ art. 321, apartado primero, se le añade un punto cinco con el siguiente texto:

Quinto.-Las disposiciones referidas a la protección del testigo amenazado son de aplicación análoga.

k) En el art. 342 se intercala un nuevo apartado segundo, convirtiéndose el actual apartado segundo en tercero:

Segundo.-La declaración de un testigo cuya identidad no conste, no puede contribuir a la prueba de que el sospechoso ha cometido el hecho que se le imputa, salvo en el supuesto previsto en el art. 190, apartado segundo, en relación con el art. 1.87-A.

1) $\mathrm{Al}$ art. 344 se le añade un apartado tercero, con el siguiente texto:

Tercero.-Los informes escritos que recojan la declaración de una persona cuya identidad no conste, pueden ser reconocidos como medio 
de prueba únicamente si esa persona es oída después como testigo por el Juez Instructor en la forma prevista en el art. 187-A, o, cuando deba aceptarse razonablemente que no pueda ser oída por el Juez Instructor, ni comparecer como testigo en el juicio. En el último supuesto, la declaración habrá de ser apoyada de forma importante por otro material de prueba.

m) En el art. 360, apartado primero, se intercala entre las palabras «art. 216, apartado segundo» $\mathrm{y}$ «da»: o de un testigo oído en la forma prevista en el art. 187-A.

\section{Artículo 2:}

En el Código Penal se introduce la siguiente modificación: tras el art. 285 se añade un nuevo artículo, con el siguiente texto:

\section{Artículo 285-A:}

Aquel que realice manifestaciones verbales, por gestos, mediante escritos o imágenes contra una persona, de la cual se pueda presumir que habrá de prestar declaración bajo juramento o una declaración equiparable como testigo o como perito, con la intención manifiesta de influir en su libertad de declarar con verdad o en conciencia, será castigado con pena privativa de libertad por un máximo de un año o multa de cuarta categoría.

En Dinamarca el Consejo Danés para procedimiento judicial, instituto que tiene por función asesorar al Ministerio de Justicia en materia de Legislación procesal, elaboró en 1985 un informe sobre la problemática del testigo anónimo, cuyas líneas generales se transcriben a continuación:

\section{La regulación danesa actual con respecto a los testigos}

Un testigo está, en general, obligado a prestar declaración en el juicio. El incumplimiento podrá penarse con seis meses de privación de libertad.

Los testigos podrán excusarse si:

A) Al prestar declaración, el testigo corriera personalmente el riesgo de incurrir en penalización o en pérdida de bienestar, o

B) Sus allegados corrieran el riesgo de incurrir en penalización o en pérdida de bienestar, $o$

C) Implicara cualquier otro daño esencial al testigo o a sus allegados.

Bajo «pérdida del bienestar» se entiende, en la práctica, también el padecimiento de molestias físicas. En el caso A), el derecho de excusa es ilimitado, mientras que en los casos B) y C) el Juzgado puede ordenar al 
testigo prestar declaración, si se considerara ésta de una importancia trascendental para el desarrollo de la causa y si la importancia del asunto fuera de tal entidad para la víctima o la sociedad que justificara la orden de prestar declaración.

El Juzgado puede ordenar que el interrogatorio de los testigos se efectúe a puerta cerrada o que el contenido de la declaración no sea publicado.

El Presidente puede determinar si el sospechoso debe abandonar la Sala durante el interrogatorio de un testigo o de un co-sospechoso en el caso que hubiera razones suficientes para suponer que de otro modo no se obtendría una declaración imparcial. En cuanto el sospechoso entre de nuevo en la Sala, habrá de serle leída la declaración informándosele, en su caso, del contenido de la misma.

La Ley no contiene ninguna definición específica sobre el mantenimiento en secreto de la identidad del sospechoso o del contenido de la declaración efectuada. En muchos Juzgados es costumbre que si el sospechoso se encuentra fuera de la Sala, pueda escuchar lo que se dice a través de un micrófono.

La sentencia del Alto Tribunal Danés de 2 de diciembre de 1983 es indicativa de la posición de la Jurisprudencia.

La utilización de testigos anónimos es admisible cuando sea plausible que el testigo o sus allegados puedan sufrir incomodo y cuando, desde el punto de vista de la justicia, la gravedad del caso y la significación de la declaración del testigo del caso hagan imprescindibles tal declaración. En tal caso el sospechoso puede quedar excluido de presenciar la declaración del testigo, pudiéndosele privar de conocer los detalles de la declaración del testigo que pudieran llevar a una revelación de la identidad del sospechoso. El condenado apeló entonces a la Comisión Europea de Derechos Humanos de Estrasburgo, la cual consideró, el 10 de julio de 1985, la queja como «manifiestamente infundada», y específicamente porque su Abogado sí estuvo presente en el interrogatorio.

\section{Argumentos a favor y en contra}

El informe contiene, además de un resumen de la bibliografía y un breve análisis de derecho comparado, un resumen de los argumentos a favor y en contra. Llama la atención que, para el Consejo, el anonimato sólo sea de importancia para aquellos testigos que no conocían al sospechoso antes de comenzar el proceso, o, por el contrario, para aquellos que no eran conocidos por el sospechoso. Pero en el caso específico, por ejemplo, de los miembros de una organización criminal o de los familiares y amigos del sospechoso, es de vital importancia que se oculte su identidad cuando declaren en contra del sospechoso. 
Como argumentos a favor de los testigos anónimos, el Consejo enumera:

1. La gravedad del crimen cometido y su grado de organización, de los que normalmente se derivan una gran amenaza y que hacen que se requiera una mayor protección de los testigos.

2. El temor creciente de muchos testigos a represalias y la menguante disposición a querer actuar como testigo.

3. La inaceptabilidad, desde el punto de vista de la justicia y de la protección de la sociedad, de que justamente las formas más graves de la criminalidad queden fuera del alcance de la ley penal por las dos razones anteriormente mencionadas.

Como argumentos en contra se citan:

a) Se dificulta la defensa del sospechoso con la actuación de testigos anónimos.

b) Si el sospechoso desconoce quién declara algo sobre él, no podrá aclarar al Juez si el testigo puede tener razones especiales para declarar en su contra, a la par que el sospechoso tampoco puede opinar, en general, sobre la credibilidad del referido testigo.

c) El hecho de que el Abogado disponga de unos determinados datos que no puede transmitir a su cliente, actúa en contra de la relación de confianza que ha de existir entre Abogado y cliente.

d) La utilización de testigos anónimos conduce a una forma de juicio secreto.

En méritos a todo lo expuesto, el Consejo Danés para el procedimiento judicial en materia de testigo anónimos propone:

\section{Apartado primero}

$\mathrm{Si}$ hubiere lugar a presuponer que pudieran correr grave peligro la vida o la salud del testigo o de sus allegados, en el caso de que la identidad del testigo fuera reconocida por el sospechoso, el Tribunal podrá resolver que el sospecho abandone la Sala durante la declaración del testigo.

Apartado segundo

Las medidas mencionadas en el apartado primero no podrán ser adoptadas, si se considerara que es importante para la defensa del sospechoso el que éste conozca la identidad del testigo. El Presidente resolverá sobre la cuestión de si el sospechoso debe abandonar la Sala, una vez que se haya decidido la cuestión de si el sospechoso dispondrá o no de la información anteriormente aludida (referente al testigo).

Apartado tercero

Fuera de los casos citados en los apartados primero y segundo, el Presidente puede resolver que un sospecho abandone la Sala durante el inte- 
rrogatorio de un testigo o co-sospechoso, si existieran razones especiales como para presuponer que de otro modo no se podría obtener una declaración realizada en total libertad.

\section{Apartado cuarto}

Si un sospechoso hubiere tenido que abandonar la Sala durante el interrogatorio de un testigo o de un co-sospechoso, habrá de ser informado, después de retornar a la Sala, sobre quién ha prestado declaración en su ausencia, al tiempo de que se reproducirá el contenido de la declaración en su presencia. Cuando la decisión haya sido adoptada conforme al apartado primero, no se comunicará al sospechoso quién ha prestado declaración en su ausencia.

En resumen, como puede observarse, la necesidad de ofrecer protección a los testigos especialmente amenazados es un sentimiento generalizado en Europa. En tales casos, el problema básico a resolver es cómo brindar las necesarias garantías al testigo sin que ello suponga un decaimiento del derecho de defensa. Cuestión, pues, de límites no siempre fácilmente definibles.

\section{Pronunciamientos jurisprudenciales}

Como cabía esperar, el tema ha sobrepasado los estudios dogmáticos y las disposiciones legales para llegar a las más altas esferas jurisprudenciales nacionales e internacionales.

Por razones de obligada brevedad centraremos nuestro estudio en el examen de la Jurisprudencia del Tribunal Europeo de Derechos Humanos, de las sentencias del Tribunal Constitucional Español y de la Sala Segunda del Tribunal Supremo.

Como punto de partida, convendrá recordar el art. 6 del Convenio Europeo para la Protección de los Derechos Humanos (Roma, 4 de noviembre de 1950), que dice así:

\section{Artículo 6}

1) Toda persona tiene derecho a que su causa sea oída, equitativa, públicamente y dentro de un plazo razonable, por un Tribunal independiente e imparcial, establecido por la Ley, que decidirá los litigios sobre sus derechos y obligaciones de carácter civil o sobre el fundamento de cualquier acusación en materia penal dirigida contra ella. La sentencia debe ser pronunciada públicamente, pero el acceso a la Sala de Audiencia puede ser prohibido a la prensa y al público durante la totalidad o parte del proceso en interés de la moralidad, del orden público o de la seguridad nacional en una sociedad democrática, cuando los intereses de los menores o la protección de la vida privada de las partes en el proceso así los exijan o 
en la medida considerada necesaria por el Tribunal, cuando en circunstancias especiales la publicidad pudiera ser perjudicial para los intereses de la justicia.

2) Toda persona acusada de una infracción se presume inocente hasta que su culpabilidad haya sido legalmente declarada.

3) Todo acusado tiene, como mínimo, los siguientes derechos:

a) A ser informado, en el más breve plazo, en lengua que comprenda y detalladamente, de la naturaleza y de la causa de la acusación formulada contra él.

b) A disponer del tiempo y de las facilidades necesarias para la preparación de su defensa.

c) A defenderse por sí mismo o a ser asistido por un defensor de su elección y, si no tiene medios para pagarlo, poder ser asistido gratuitamente por un Abogado de oficio, cuando los intereses de la justicia lo exijan.

d) A interrogar o hacer interrogar a los testigos que declaren contra él e interrogar a los testigos que declaren en su favor en las mismas condiciones que a los testigos que lo hagan en su contra.

e) A ser asistido gratuitamente de un intérprete, si no comprende o no habla la lengua empleada en la Audiencia.

Obvio es decir que el referido precepto, al haber ratificado España el tratado de Roma, tiene fuerza vinculante en el Estado Español (art. 10-2 de la Constitución).

Aun cuando la interpretación del mencionado precepto ha sido objeto de numerosas sentencias del Tribunal Europeo de Derechos Humanos, por su directa conexión con el tema estudiado, nos limitaremos al examen de tres resoluciones de dicho Tribunal: los casos Kostovski (sentencia 20 noviembre 1989), Windisch (sentencia 27 septiembre 1990) y Ludi (sentencia 15 junio 1992).

\section{Caso Kostovski}

Kostovski fue detenido, acusado de haber participado en el atraco a mano armada de una entidad bancaria, junto con otros dos co-reos, merced a la denuncia presentada en sede policial por dos personas que solicitaron guardar anonimato por temor a represalias.

Dichos testigos prestaron declaración de nuevo en el Juzgado de Instrucción, conservando su anonimato, impidiéndose asistir a la defensa, si bien posteriormente se facilitó a ésta última una copia de las declaraciones anónimas, invitándole a que presentase un cuestionario de preguntas para los referidos testigos, pero advirtiéndole que no podría estar presente cuando los testigos contestasen al cuestionario. 
Planteadas por el Abogado defensor 14 preguntas, dirigidas en su mayoría a averiguar las circunstancias en las cuales el testigo había obtenido su conocimiento de los hechos, fueron declaradas pertinentes solamente dos de ellas.

Los testigos anónimos no comparecieron al acto del juicio oral, procediéndose únicamente a la lectura en dicho acto de sus declaraciones anteriores, que fueron admitidas como prueba de convicción. El Tribunal de instancia condenó a Kostovski a la pena de seis años de prisión como autor de un delito de robo a mano armada, sentencia que fue confirmada en apelación y casación.

Kostovski recurre ante el Tribunal Europeo de Derechos Humanos invocando la violación el art. 6 del Convenio Europeo para la protección de los derechos humanos y el Tribunal reconoce haberse violado los párrafos primero y tercero de dicho precepto, al haberse utilizado como prueba de cargo la declaración de dos testigos anónimos que no pudieron ser directamente interrogados por la defensa ni en el Juzgado de Instrucción, ni ante el Tribunal sentenciador («si la defensa ignora la identidad de un individuo que trata de interrogar, puede verse privada de precisiones que le permitan establecer que es parcial, hostil o indigno de fe». "Además, la ausencia de dichas personas anónimas impidió al Tribunal sentenciador estudiar su comportamiento durante el interrogatorio, para de este modo formarse, por sí mismo, una opinión sobre su credibilidad»).

Con todo, el Tribunal Europeo de Derechos Humanos admite en esta sentencia la posibilidad de utilizar testigos anónimos durante la fase de instrucción de la causa.

A los efectos que interesan en relación con este trabajo, conviene remarcar que la razón fundamental del Tribunal Europeo de Derechos $\mathrm{Hu}$ manos para entender que hubo violación del art. 6 no es sólo que los testigos anónimos no compareciesen ante el Tribunal Sentenciador: es que no pudieron ser convenientemente contrainterrogados por la defensa en ningún momento del procedimiento ${ }^{6}$.

\section{Caso Windisch}

Muy similar al anterior y con idéntico fallo por parte del Tribunal Europeo de Derechos Humanos.

Perpetrado un robo en un café, dos mujeres se presentaron ante la Policía y con la promesa de que sería guardado su anonimato declararon

\footnotetext{
${ }^{6}$ La sentencia completa del Tribunal Europeo de Derecho Humanos en el «caso Kostovski» puede ser consultada en Publications de la Cour Européenne des Droits de l'Homme. Serie A: Arrets et dècisions. Vol. 166.
} 
ante ella que el día en que se cometieron los hechos y en sus proximidades vieron a un sujeto pasar en un vehículo con el rostro semitapado con un pañuelo, lo que les indujo a tomar la matrícula del mismo; ello condujo a la detención de Windisch.

Mostradas que les fueron por la Policía a las testigos diversas fotografías de dicho hombre, lo reconocieron como la persona a la que habían visto en las circunstancias ya indicadas el día de autos. Practicada una rueda de reconocimiento por parte de las testigos, Windisch fue reconocido, con la cara semitapada, por las dos mujeres.

En las sesiones del juicio oral el Tribunal rechazó la petición de la defensa de que fuesen convocadas al mismo las dos mujeres, ya que éstas temían represalias; el testimonio y la identificación de las mismas ante la Policía bastó para que el Tribunal considerase a Windisch culpable y lo condenase a una pena de tres años de prisión. La Corte de casación confirmó la sentencia .

Recurrido el fallo ante el Tribunal Europeo de Derechos Humanos sobre la base de haberse dictado la condena en méritos al testimonio de dos testigos anónimos que no habían sido oídos en el juicio oral, impidiéndose con ello el interrogatorio por parte de la defensa, la Corte Europea entendió haberse violado el art. 6-1 y 3 d) de la Convención por idénticas razones al caso Kostovski, y ello a pesar de reconocer que el empleo de testigos anónimos durante la instrucción preparatoria era una práctica legal.

Es de remarcar que, en la causa que nos ocupa, ni siquiera el Tribunal sentenciador conocía la identidad de los testigos anónimos?

\section{Caso Lüdi}

Guarda cierto parecido con los anteriores, aunque con algunas matizaciones.

Lüdi fue condenado por narcotráfico como consecuencia del testimonio de un policía infiltrado, que mantuvo su anonimato durante el procedimiento y no declaró en persona ante el Tribunal para evitar «quemar» a dicho agente en otros procesos antidroga.

El Tribunal Europeo de Derechos Humanos constata que este caso se diferencia de los asuntos Kostovski y Windisch por cuanto en la causa seguida contra Lüdi el testigo de cargo lo era un policía que había prestado juramento y el recurrente le conocía si bien no por su identidad sí por su apariencia física, toda vez que lo había visto en cinco ocasiones.

7 La sentencia íntegra dictada por la Corte Europea puede consultarse en: Publications de la Cour Européenne des Droits de l'Homme. Serie A: Arrets et dècisions. Vol. 166. 
Ello no obstante - y con un voto particular en contra-, la Corte Europea estimó infringido el art. 6-1 y 3 d) de la Convención, a virtud del siguiente razonamiento:

«Ni el Magistrado ni las Jurisdicciones pudieron o quisieron escuchar a Toni (agente infiltrado) y proceder a una confrontación destinada a comparar las declaraciones de éste con las alegaciones del Sr. Lüdi; además, ni éste último ni su asesor legal tuvieron en ningún momento del procedimiento la ocasión de interrogar o de abrigar alguna duda sobre su credibilidad. Hubiera sido posible, sin embargo, hacerlo teniendo en cuenta el interés legítimo de las autoridades de Policía, en un asunto de tráfico de estupefacientes, de preservar el anonimato de su agente para poder no sólo protegerle, sino también para utilizarlo de nuevo en el futuro.» ${ }^{8}$

\section{Resumen}

En las tres sentencias del Tribunal Europeo de Derechos Humanos que se acaban de transcribir se dan una serie de factores comunes:

a) los testigos, en todo caso, fueron absolutamente anónimos,

b) no se permitió la presencia de dichos testigos en el acto del juicio oral y,

c) la defensa no tuvo oportunidad de interrogarlos directamente en ninguna fase del procedimiento.

Cuál hubiera sido el criterio del Tribunal Europeo de Derechos Humanos si los testigos, aun anónimos para las partes, hubiesen comparecido en el juicio oral, hubiesen sido interrogados en el mismo y cabiendo en consecuencia al Tribunal formarse un juicio directo acerca de su credibilidad, es algo que no ha quedado aclarado, por no debatido.

\section{Jurisprudencia del Tribunal Constitucional Español}

Al Tribunal Constitucional Español nunca se le han presentado casos como los anteriormente señalados; ello no obstante, en su sentencia de fecha 28 febrero 1994, corrigiendo algunos excesos hipergarantistas de

8 El texto íntegro de la sentencia puede hallarse en: Cour Européenne des Droits de l'Homme: 17/1991/269/340. El voto particular disintiendo del fallo dictado por la mayoría estimaba no haberse producido violación del art. 6 de la Convención por cuanto la utilización de agentes infiltrados por parte de la Policía en su lucha contra el terrorismo y contra el narcotráfico era un procedimiento legítimo, dentro de ciertos límites. 
la Sala Segunda del Tribunal Supremo', sienta una doctrina de cierto interés al respecto.

Los hechos sometidos a debate en ella fueron los siguientes: el Sr. R.M. fue condenado por el Juzgado de lo Penal núm. 18 de Madrid como autor de un delito de robo con intimidación y otro de amenazas, resolución que fue confirmada, sustancialmente, en grado de apelación, por la Audiencia Provincial de Madrid, contra cuyas sentencias se alza en recurso de amparo - a los efectos que aquí interesa - alegando violación del art. 24 de la Constitución Española (derecho a un proceso con todas las garantías) por cuanto, al decir del recurrente, la única prueba practicada en el juicio - declaración de la víctima y de su madre - fue practicada en el despacho contiguo del Magistrado de lo Penal y no en la sala de vista, lo que motivó que la defensa del encausado no pudiese interrogar a los precitados testigos y que los declarantes no identificasen al acusado a presencia de todos los asistentes.

El Tribunal Constitucional deniega el amparo solicitado en base a los razonamientos que a continuación se transcriben:

\section{Fundamentos Jurídicos:}

«1) Denuncia el actor en el presente supuesto, como fundamento de su petición de amparo, la vulneración de una pluralidad de derechos fundamentales: concretamente, de los derechos a la presunción de inocencia, a un proceso con todas las garantías, a la utilización de los medios de prueba pertinentes y a no sufrir indefensión, consagrados todos ellos en el art. 24 de la Constitución Española.

Ya más concretamente, la infracción de los dos primeros derechos señalados se hace derivar por el recurrente en su argumentación de que la única prueba practicada en el acto del juicio oral — declaración testifical de la víctima del delito y de su madre- no se practicó con las debidas garantías, por lo que debe considerarse inválida o nula; y, en consecuencia, al ser ésta la única prueba que fundamenta la condena, se produce así mismo infracción del derecho de presunción de inocencia, al no quedar ya ninguna en la que fundamentar la convicción de culpabilidad del Juzgador.»

«2) Estas dos lesiones esenciales en que se fundamenta la queja del actor se reconducen a un hecho básico que constituye el núcleo de su denuncia ante esta sede: la afirmación de que la declaración de la víctima del delito y de la otra testigo, propuesta por la acusación pública (madre del perju-

9 Así, la Sala Segunda del Tribunal Supremo ha declarado nula la declaración de un testigo cuya identidad es conocida, en el acto del juicio oral, pudiendo ser interrogado por todas las partes, por el simple hecho de que dicho testimonio no se prestase a presencia del acusado, aunque sí de su Abogado defensor (sentencias de 20 febrero 1989, 17 septiembre 1990 y 8 mayo 1991). 
dicado), se prestaron en el acto de la vista sin ser vistos ni oídos por la defensa, o, dicho de otro modo, fuera de la Sala de Audiencia, y, por lo tanto, sin la presencia del acusado ni de su representación y defensa procesales.

Pues bien, antes de analizar la eventual lesión de los dos derechos fundamentales inicialmente apuntados, será preciso clarificar, ante todo, si, en efecto, hubo en este supuesto alguna irregularidad procesal en la forma de practicar la prueba testifical en el acto del juicio, así como, en su caso, en qué consistió tal irregularidad; y todo ello con objeto de centrar ya inicialmente y en sus justos términos los hechos en que se basa la petición de amparo. De la lectura del acta que documenta la correspondiente vista del juicio se desprende que los testigos propuestos por la acusación (el perjudicado y su madre) fueron examinados sin ser vistos, más no sin ser oídos por la defensa. Así, puede leerse textualmente en el acta: "...los testigos solicitan ser interrogados en ausencia del acusado, el Ministerio Fiscal no se opone, oponiéndose la defensa. Su Señoría acuerda interrogar a los testigos en presencia del acusado, sin que puedan ser vistos por el mismo". Este hecho de que el acusado no podía ver a los testigos se reconoce también en el fundamento jurídico tercero de la sentencia dictada en apelación. Pero, por el contrario, que los testigos eran escuchados por la defensa se desprende tanto de la anterior expresión del acta a que se ha hecho referencia, como también del dato -igualmente consignado en aquélla - de que la defensa interrogó a los dos en dicho acto. Por tanto, la irregularidad que se afirma por el demandante de amparo consistió en el hecho de que los testigos declararon sin ser vistos por el acusado y su defensa, más no sin ser oídos por aquél. Tampoco cabe afirmar que el acusado no conociese sus datos de identificación, esto es, no se trataba en esta ocasión de testimonios anónimos ni, en fin, de que el Juez se encontrara ausente en dicha declaración testifical. Así mismo, importa destacar que entre los hechos enjuiciados en dicho proceso penal se encontraba la denuncia de unas amenazas inferidas al perjudicado por el acusado en las horas inmediatamente posteriores a la perpetración del robo; y que fueron tanto la víctima como el otro testigo de cargo los que solicitaron, al inicio de la vista, prestar declaración "en ausencia" del acusado.

No cabe duda que tal forma de prestar declaración en el acto del juicio constituye una cierta anomalía procesal, pues, en primer término, no es ordinaria y frecuente y, además, no parece adecuarse a los términos literales del art. 229-2 de la Ley Orgánica del Poder Judicial, que establece textualmente "...las declaraciones, confesiones en juicio, testimonios, careos... se llevarán a efecto ante el Juez o Tribunal con presencia o intervención, en su caso, de las partes y en audiencia pública, salvo lo dispuesto en la Ley".

Ahora bien, este Tribunal viene señalando de manera reiterada que no es únicamente la constatación de una determinada irregularidad procesal lo que dota de relevancia constitucional a la queja de amparo, sino la inci- 
dencia real que aquella tenga en el supuesto concreto sobre los derechos fundamentales cuya vulneración se invoca. Por tanto, lo que hemos de examinar a continuación, a fin de determinar si la presente petición de amparo debe o no ser estimada, no es la irregularidad en sí misma, sino su relevancia desde la perspectiva de aquellos dos derechos fundamentales que constituyen esencia de la queja anterior.»

«3) Desde la primera perspectiva apuntada, esto es, del derecho a un juicio público con todas las garantías consagrado en el art. 24-2 de la norma fundamental, la declaración testifical controvertida ha de analizarse a su vez desde una triple vertiente de exigencias, que se resumen en las siguientes: publicidad, contradicción e igualdad de armas, con el fin de determinar si éstas se observaron en efecto o no en este supuesto concreto.

La primera exigencia, esto es, la publicidad del proceso, no puede entenderse vulnerada en este caso porque, al margen de aquella anómala forma de declaración, el juicio se celebró en la sede del Tribunal y se documentó en la correspondiente acta, sin que consten restricciones de acceso a su celebración o de obtener y difundir información acerca del mismo. Por tanto, la finalidad o razón de ser del derecho a un juicio público, que no es otra que la posibilidad de que el funcionamiento de los Tribunales sea de conocimiento público y pueda ser sometido al control de los justiciables, no se ha visto empañado en modo alguno en este caso.

Ahora bien, desde la perspectiva de las garantías que consagra el art. 24-2 de la Constitución Española, la cuestión ha de examinarse, conforme se indicó, en relación con dos exigencias básicas: posibilidad de contradicción y de igualdad de armas en el proceso, esto es, real ejercicio de la defensa.

La primera de esas exigencias, la contradicción procesal, deriva directamente del art. 6-3 d) del Convenio Europeo de Derechos Humanos, a la luz del cual ha de interpretarse el art. 24-2 de la Constitución Española por exigencia del art. 10-2 de la Norma fundamental. El art. 6-3 d) del Convenio exige que el acusado pueda interrogar o hacer interrogar a los testigos de cargo en las mismas condiciones que los de descargo. Por tanto, la cuestión que surge es si puede entenderse cumplido tal requisito en aquellos supuestos como el que nos ocupa, en el que los testigos de cargo prestan su declaración sin ser vistos por el acusado, aunque sí oídos. El Tribunal Europeo de Derechos Humanos ha examinado en diversas sentencias el problema, pero referido más bien a los testimonios anónimos, es decir, aquellos en los que la identidad de los testigos era desconocida para el Tribunal o para la defensa o para ambos. En este sentido pueden citarse la sentencias de Kostovski, de 20 de noviembre de 1989 y Windisch, de 27 de septiembre de 1990, o, finalmente, la sentencia Lüdi, de 15 de junio de 1992. En estas resoluciones ha reconocido el Tribunal Europeo de Derechos Humanos la importancia de proteger a los testigos susceptibles de ser objeto de represalias y de permitir el enjuiciamiento y condena de delincuentes pertenecientes a bandas organizadas o miembros de una gran criminalidad (sentencias Ciulla y Kostovski) mostrando asi- 
mismo comprensión hacia la necesidad de garantizar y estimular la colaboración de los ciudadanos con la Policía en la lucha contra la criminalidad (sentencia Windisch). Pero, aun así, y en dos de las precitadas sentencias (casos Kostovski Windisch) ha estimado contrario a las exigencias derivadas del Convenio Europeo de Derechos Humanos la condena de un acusado sobre la base de testimonios anónimos, entiendo por tales las declaraciones de personas cuya identidad es desconocida por el Tribunal, por la defensa, o por ambos, pues ello conduce a una restricción de los derechos de defensa al imposibilitar la contradicción ante el órgano judicial encargado de decidir sobre la inocencia o culpabilidad. En el caso Lüdi, insistió en la importancia de posibilitar la contradicción del testimonio de cargo, aunque en esta ocasión se tratase de persona (funcionario de Policía) cuya identidad era necesario proteger.

La referencia a la anterior doctrina del Tribunal Europeo de Derechos Humanos permite, pues, concluir que es la imposibilidad de contradicción y el total anonimato de los testigos de cargo lo que el citado Tribunal considera contrario a las exigencias derivadas del art. 6 del convenio; por lo que, por el contrario, en aquellos casos, como el presente, en el que el testimonio no puede calificarse de anónimo sino, en todo caso, de «oculto» (entendiendo por tal aquel que se presta sin ser visto por el acusado), pero, en los que la posibilidad de contradicción y el conocimiento de la identidad de los testigos - tanto para la defensa como para el Juez o Tribunal llamado a decidir sobre la culpabilidad o inocencia del acusadoresulten respetados, han de entenderse cumplidas la exigencias derivadas del art. 6-3 d) del Convenio y, en consecuencia, también las garantías que consagra el art. 24-2 de nuestra Constitución.

En el caso, el examen de lo actuado, y especialmente la lectura del acta del juicio oral, permite constatar que la identidad de los declarantes (testigos de cargo) fue perfectamente conocida por el Tribunal y por la defensa, así como que esta última pudo hacer las preguntas que tuviera por convenientes a los mismos, pues así se refleja en el acta (a salvo, evidentemente, de aquellas cuya impertinencia o improcedencia fue estimada por el Juez en el ejercicio de su función). Todo ello determina que la contradicción no puede entenderse restringida en este supuesto, pese a la controvertida forma de efectuar la declaración.»

«Lo dicho hasta ahora ha de llevar a concluir que la primera queja del presente recurso de amparo - vulneración al derecho a un juicio público con todas las garantías - ha de desestimarse.»

De los razonamientos de la anterior sentencia se infiere que es «la imposibilidad de contradicción y el total anonimato» de los testigos de cargo lo que supondría violación del derecho a un proceso con todas las garantías, de tal modo que, si la defensa del acusado pudo escuchar al testigo —conocido- (aunque no lo viese) y contrainterrogarle, no hay vulneración del art. 24 de la Constitución Española. Doctrina íntegra- 
mente ratificada por otra resolución posterior del Tribunal Constitucional del año 1994, examinando un supuesto de hecho similar al anterior.

\section{Jurisprudencia menor}

Para finalizar con este capítulo dedicado a precedentes jurisprudenciales, merece traerse a colación — bien que se trate de «pequeña Jurisprudencia»- el auto dictado por el Juzgado de Instrucción núm. 5 de Bilbao, de fecha 8 abril 1992, en el sumario núm. 5/91, entre otras razones porque los hechos origen de las precitadas diligencias fueron, en cierto modo, el detonante de la Proposición de Ley de Protección de Testigos presentada por el Partido Nacionalista Vasco.

El auto aludido es del siguiente tenor literal:

\section{HECHOS}

Primero: En este Juzgado se sigue sumario núm. 5/91 por la muerte de José María Ormazábal Ibargüen acaecido en el Parque de Etxebarria de esta ciudad el día 29 de agosto de 1991, sumario en el que aparecen personados en legal forma el Procurador Sr. Atela Arana, en nombre y representación del Gobierno Vasco, y la Procuradora Alday Mendizábal, en nombre y representación de los familiares de José María Ormazabal Ibargüen.

Segundo: La representación legal del Gobierno Vasco en sus escritos de fecha 20 de enero y 20 de febrero de 1992 y refiriéndose a la realización de la que se considera una diligencia de inminente práctica en la presente instrucción - la declaración de los agentes de la Policía Autónoma Vasca, intervinientes en el suceso referido-, solicitan la adopción de alternativas jurídicas diversas, a saber: 1) que se declaren secretas las actuaciones al amparo de lo establecido en el art. 302 de la Ley de Enjuiciamiento Criminal; 2) que se acuerde la práctica de la declaración de los funcionarios policiales «sin que el acusador privado ni el actor civil estén presentes en el interrogatorio» en base a lo dispuesto en el art. 385 del mismo texto legal y 3) que además se adopten las medidas precisas para que el acceso y la comparecencia de los citados agentes se lleve a cabo en condiciones tales de tiempo, modo y lugar que preserven su imagen y su identidad.

Para fundamentar sus súplicas dicha parte argumenta que la presente instrucción se refiere a un acontecimiento violento, producido en el curso de una actuación policial dirigida contra la delincuencia terrorista, que hace necesario en consecuencia garantizar el anonimato de los que trabajan contra ella, considerándose además tal reserva indispensable no sólo para la eficacia futura de la acción policial, sino más aún, para la protección de la propia vida y de la integridad de los agentes.

\section{RAZONAMIENTOS JURIDICOS}

Primero: No lejos de las reflexiones vertidas en los escritos indicados, se halla el ánimo de esta instructora que compartiendo plenamente 
los planteamientos expuestos por la representación legal del Gobierno Vasco y para evitar en la medida de lo posible que los agentes puedan convertirse en objetivos de eventuales represalias, acordó en resolución devenida firme de fecha 14-10-91, que su identidad quedara resguardada conveniente en la Secretaría de este Juzgado, a salvo de cualquier curiosidad que por ella pudieran sentir todos aquellos que tienen acceso a la causa, bien por estar personados en ella o bien por cualquier otra forma de relacionarse con la misma, preservando así del ávido interés que sin duda despertaría en los medios de comunicación la divulgación del nombre, documento nacional de identidad, número profesional, domicilio... y demás datos de los funcionarios policiales.

Basta por tanto continuar con la medida ya adoptada y prolongarla en la continuación de las actuaciones para dejar a salvo la identidad de los policías, quedando en consecuencia tan sólo por decidir respecto a las diversas sugerencias formuladas por el Gobierno Vasco la referida a la reserva de la imagen de los agentes, siendo obligado en este punto poner tales pedimentos en relación con los principios básicos y con la propia legislación que rige nuestro sistema procesal penal.

Segundo: En este sentido se pide en primer lugar que se declaren secretas las actuaciones (art. 302 de la Ley de Enjuiciamiento Criminal), imaginemos que únicamente en cuanto a la diligencia de declaración de los agentes.

No puede olvidarse que en nuestra vigente Ley, la regla general establece que las actuaciones y diligencias del procedimiento en el período instructorio no tienen carácter secreto para las partes personadas, a no ser que excepcionalmente se acuerde que así sea por considerarse que la investigación de los hechos presuntamente delictivos, su esclarecimiento, la exculpación o inculpación de los imputados, y, en suma, el buen fin de importantes o decisivas actuaciones aconsejen o exigen que los interesados no tomen conocimiento de la causa. No es ésta en absoluto la circunstancia en la que nos hallamos, dado que pocas diligencias quedan por practicar en esta instrucción que interesen tanto a las partes personadas como a las declaraciones de sus protagonistas, no suponiendo además ningún riesgo para la buena marcha de la investigación el hecho de que las mencionadas manifestaciones sean presenciadas y conocidas por ambas partes.

Es mención obligada asimismo indicar cómo en nuestra vigente normativa el principio de publicidad o de secreto de las actuaciones se ve presidido por la necesaria igualdad «inter partes», es decir, el procedimiento podrá ser público o podrá ser total o parcialmente secreto, según se haya acordado, pero tal carácter lo tendrá para todas las partes, sin discriminación alguna, sean acusadores o presuntamente inculpados. Tal cosa conlleva irremediablemente a concluir que si se declarasen secretas las diligencias a practicar, se estaría impidiendo a los agentes el ejercicio de derechos básicos y fundamentales reconocidos legal e incluso constitucionalmente (art. 118 de la Ley de Enjuiciamiento Criminal, 24 y 17 de 
la Constitución y concordantes) puesto que tampoco sus Letrados podrían asistir a la práctica de sus declaraciones de accederse a tal medida, pudiéndose presumir sin riesgo a equivocarse que tal consecuencia es bastante alejada del deseo de quienes precisamente pretenden el secreto.

El obstáculo recién mencionado se solventaría, no obstante, con el acogimiento de la posibilidad establecida en el art. 385 de la Ley de Enjuiciamiento Criminal, dado que con tal precepto tan sólo estarían ausentes de la práctica de las declaraciones el acusador privado y el actor civil. Debe precisarse, sin embargo, que a falta de un motivo apreciable como suficiente para fundamentar la adopción de tal excepcional medida, la misma no es procedente, atreviéndonos además a asegurar que el ánimo de la parte que la solicita no es tanto privar a su contraria de su derecho a asistir y participar en la práctica de la tantas veces mencionadas declaraciones de los policías, cuanto asegurar su anonimato.

Esta y no otra es la aspiración que ha de tratar de conseguir la presente resolución: la protección de la imagen de los funcionarios policiales, finalidad que habrá de lograrse no a toda costa sino dejando a salvo los principios procesales más básicos y fundamentales de nuestro ordenamiento.

En este sentido, ningún inconveniente aprecia esta instructora para permitir que los agentes acudan a llamamiento judicial y lleven a cabo su declaración —después, eso sí, de comprobarse y asegurarse su identidad en la Secretaría de este Juzgado - utilizando los disimulos que consideren oportunos para lograr entorpecer la visión que de ellos puedan obtener los interlocutores, valiéndose en su caso de los artificios que entiendan convenientes para ocultar sus características físicas o desfigurar sus rostros.

De esta forma no sólo se preserva la imagen de los agentes respecto a los presentes en la práctica de la declaración sino, lo más importante, se protege también del público en general. Y es que no duda esta instructora por las experiencias no tanto vividas como conocidas en supuestos similares al presente, que, dado cual es la naturaleza del asunto que nos ocupa, los medios de comunicación tratarán de captar sin recatos y divulgar sin pudor cuantas imágenes les sea posible obtener, y ello a pesar de hallarnos en una fase, la de instrucción del sumario, caracterizada por el secreto para todos los que no sean parte en la causa (art. 301 de la Ley de Enjuiciamiento Criminal) a diferencia de lo que ocurre en la celebración del acto del juicio oral.

Sería tal vez una ingenuidad y una equivocación pensar que el «instinto» de los informadores — sin duda potenciado por la notoriedad del hecho que se investiga - no vaya a «adivinar» el lugar y el día en que las declaraciones van a practicarse, y ello por muchas cautelas que se adopten y por muy insólito e inimaginable que fuera ese sitio y ese momento. Tales motivos obligan a que ninguna variación se adopte respecto al normal desenvolvimiento de espacio y tiempo con que vienen desarrollándose las múltiples y diversas declaraciones que en este Juzgado se practican. 
Puede asegurarse, no obstante en esta resolución que no va a ser precisamente el Juzgado quien comunique a los informadores cuándo y dónde van a declarar los policías, que ningún integrante de los medios de comunicación estará presente ni tendrá acceso al despacho en que las declaraciones se practiquen, y que además se adoptarán las medidas de orden necesarias y precisas en la entrada y estancia del mismo.

Pero los demás prolegómenos de seguridad y vigilancia que se crean conveniente y que vayan referidos al acceso, entrada y libre circulación de la prensa y el público en general de este Palacio de Justicia en el que tiene su sede este Juzgado no es una competencia que corresponda al mismo, siendo el Excmo. Sr. Presidente de este Tribunal Superior de Justicia el único que puede disponer al respecto y a quien en su caso habrá de dirigirse la oportuna solicitud, siempre que se siga considerando oportuno hacerlo. ción.

Vistos los artículos y demás preceptos de general y pertinente aplica-

En atención a lo expuesto:

DISPONGO: Que no ha lugar a decretar el secreto parcial del presente sumario en lo relativo a las declaraciones que los agentes de la Policía Autónoma Vasca han de llevar a cabo. Así como tampoco procede la aplicación de lo establecido en el art. 385 de la Ley de Enjuiciamiento Criminal en la realización de tal diligencia.

Procédase a citar a los agentes de la Policía Autónoma Vasca en el concepto que se indicará en los despachos oportunos, y ello una vez sea firme la presente resolución, indicándoles a los mismos que podrán acudir al llamamiento judicial haciendo en su caso uso de las facultades que les han sido reconocidas en el fundamento jurídico segundo de la presente resolución.

Este auto es la mejor demostración de cómo, aplicando el puro sentido jurídico común, sin necesidad de acudir a grandes construcciones doctrinales, ni a preceptos legales y jurisprudenciales, se pueden resolver problemas razonablemente, garantizando sustancialmente los intereses en conflicto, al menos en la fase de instrucción.

\section{La proposición de ley del Partido Nacionalista Vasco}

Los antecedentes que se acaban de reseñar evidencian la existencia de un sentimiento generalizado: la necesidad de brindar medidas de protección, de uno u otro tipo, a aquellos testigos que, por cumplir con el deber cívico de colaborar con la Administración de Justicia, pueden sentirse amenazados; riesgo mayor cuando quien está implicado no es un delincuente individual sino una organización criminal, cual sucede principalmente en Europa con el terrorismo y el narcotráfico. 
Si a ello se añade un fenómeno local - la campaña de acoso y derribo sistemática e indisimuladamente emprendida contra la Policía Autónoma Vasca por un sector radical de todos conocido-, se comprende que el Partido Nacionalista Vasco emprendiese una iniciativa legislativa presentando una Proposición de Ley de Protección de denunciantes, testigos y peritos en determinadas causas criminales, cuyo texto literal era el siguiente:

\section{EXPOSICION DE MOTIVOS}

La experiencia diaria enseña las reticencias de los ciudadanos a colaborar con los cuerpos policiales y con la Administración de Justicia en las causas penales incoadas con motivo u ocasión de los hechos delictivos cometidos por elementos terroristas, por personas integradas en bandas armadas o por grupos criminales organizados, ante el natural temor a sufrir sus represalias.

Ello conlleva, con frecuencia, que no se pueda contar con testimonios y pruebas valiosas para el éxito de la investigación, con la consiguiente impunidad de los culpables.

Tal situación no es exclusiva de la sociedad española como lo demuestra el hecho de que otros países, de reconocido talante democrático, hayan dictado ya, o se hallen en avanzadas vías de hacerlo, una específica legislación protectora de los testigos llamados a deponer en los procesos penales dirigidos contra miembros de la llamada delincuencia organizada.

Siguiendo el ejemplo del derecho comparado - valgan como botón de muestra Italia, Estados Unidos y Alemania - se ha considerado oportuno promulgar una serie de normas que protejan la seguridad de denunciantes, testigos y peritos, garantizando el secreto de su identidad frente a terceros en la fase policial y judicial instructora, algo que ha sido admitido ya por el Tribunal Europeo de Derechos Humanos en sus sentencias de 29 de septiembre de 1990 (caso Windisch) y 20 de noviembre de 1989 (caso Kostovski).

Disposiciones que, por razones evidentes, han de extender sus efectos protectores, igualmente, a los miembros de las fuerzas policiales involucradas en la lucha contra la delincuencia violenta organizada, tanto para salvaguardar su seguridad personal como para mantener la eficacia del servicio.

Resulta obvio - como también se desprende de las sentencias precitadas- que tales garantías para denunciantes, testigos y peritos no pueden ser ilimitadas, ni violar el derecho de defensa de los justiciables («principio de igualdad de fuerzas»), razón por la cual, una vez abierto el juicio oral, y sólo entonces, si cualquiera de las partes lo solicitara, habrá de facilitársele únicamente el nombre y apellidos de quienes vayan a prestar declaración o rendir informe en la causa. Con ello se salva el derecho a un proceso con todas las garantías, ya que tal derecho se satisface con la posibilidad de saber quién o quiénes son las personas que han de ser utilizadas para articular una prueba procesal de cargo, sin que sea necesario 
facilitar otros datos sobre las mismas, tales como su domicilio, residencia o centro de trabajo, ni siquiera su imagen física, que podrá ser preservada incluso en las sesiones del debate oral.

Por otro lado, la protección a denunciantes, testigos y peritos no se satisface plenamente con la salvaguarda de su identidad, requiriéndose medidas complementarias como, por ejemplo, la protección policial de los mismos durante el proceso y aun hasta cierto tiempo después de concluido el mismo, e incluso la eventual concesión de ayudas económicas en aquellos casos excepcionales en que el testigo o perito hubieren de abandonar temporal o definitivamente su domicilio u ocupación habitual.

Finalmente, una adecuada protección de las personas comprendidas en la presente Ley exige que las mismas, o en su caso, sus más allegados parientes, sean objeto de una indemnización por parte del Estado cuando hubieren sufrido un ataque en su vida, integridad corporal o bienes como consecuencia directa del testimonio prestado o informe rendido.

La proposición de Ley que ahora se presenta trata de compaginar ese difícil pero necesario equilibrio entre las garantías procesales del justiciable y derechos tan importantes como la vida, integridad o seguridad de aquellas personas que cooperan con la Administración de Justicia.

\section{Artículo 1:}

Primero.-Las disposiciones de esta Ley son aplicables a quienes en calidad de denunciantes, testigos o peritos, intervengan de cualquier modo en los procesos penales incoados:

a) Con motivo u ocasión de actos delictivos cometidos por elementos terroristas, personas integradas en bandas armadas, o vinculadas a las mismas, así como por grupos criminales violentos organizados, o,

b) Como consecuencia de la investigación o persecución, por parte de las fuerzas de seguridad, de los hechos a que se refiere el párrafo anterior. En este caso, también serán de aplicación las disposiciones de la presente Ley a los miembros de las Fuerzas de Seguridad denunciados o querellados, en tanto no se aprecien, por la autoridad judicial indicios racionales de criminalidad en su conducta.

Segundo.-Para que vengan en aplicación las disposiciones de la presente Ley será necesario que pueda presumirse, racionalmente, un peligro grave para la persona, libertad o bienes de quienes pretendan ampararse en ella; para su cónyuge o persona a quien se hallen ligados por análoga relación de afectividad; para sus ascendientes, descendientes o hermanos, o para la eficacia o seguridad del servicio en el caso del núm. 1-b) de este artículo.

\section{Artículo 2:}

Los denunciantes, testigos o peritos a que se alude en el artículo anterior podrán exigir de los funcionarios policiales, del Ministerio Fiscal y Autoridades Judiciales intervinientes en dichos procesos: 
a) Que se preserve su anonimato, salvo frente al órgano jurisdiccional competente para instruir la causa, al Ministerio Fiscal y a los funcionarios policiales intervinientes en la misma, en tanto no se decrete la apertura del juicio oral.

b) Que se les brinde protección policial durante el proceso y por el tiempo que prudencialmente se estime conveniente tras la finalización del mismo.

c) En casos excepcionales, cuya determinación se hará reglamentariamente, que se les faciliten documentos de una nueva identidad y medios económicos para cambiar su residencia o lugar de trabajo.

\section{Artículo 3:}

Para garantizar el cumplimiento de lo prevenido en el apartado a) del artículo anterior, a solicitud del interesado, las autoridades y funcionarios aludidos en el mismo:

a) Se abstendrán de hacer constar en las diligencias que practiquen el nombre, apellidos, domicilio, lugar de residencia o trabajo y profesión del denunciante, testigo o perito, así como de cualquier otro dato que pudiera servir para la identificación de los mismos.

En tales casos, la verdadera identidad del denunciante, testigo o perito sólo será conocida por las autoridades policiales, fiscales y judiciales intervinientes, quienes la conservarán con carácter reservado, siendo asignado al denunciante, testigos o perito un número o cualquier otra clave con la que será identificado a lo largo de todas las actuaciones.

Cada vez que el denunciante, testigo o perito preste declaración o emita informe se identificará únicamente ante las precitadas autoridades.

b) Los denunciantes, testigos o peritos podrán comparecer durante todo el proceso con el rostro cubierto o utilizando cualquier otro procedimiento que imposibilite su identificación visual u oral.

c) Igualmente podrán solicitar que, para la práctica de cualquier diligencia, se fije como domicilio, a efectos de citaciones o notificaciones, las dependencias policiales o judiciales intervinientes, quienes se encargarán de hacerlas llegar, reservadamente, a su destinatario.

d) Los miembros de la Fuerzas y Cuerpos de Seguridad, el Ministerio Fiscal y la autoridad judicial, cuidarán de evitar que a tales denunciantes, testigos o peritos se les hagan fotografías o se tome su imagen por cualquier otro procedimiento, debiendo proceder a retirar el material fotográfico, cinematográfico, videográfico o de cualquier otro tipo a quien contraviniere esta prohibición. Dicho material será devuelto a su titular una vez comprobado que no existan vestigios de tomas en los que aparezcan los denunciantes, testigos o peritos de forma tal que pudieran ser identificados.

e) Los denunciantes, testigos o peritos podrán solicitar ser conducidos a las dependencias judiciales, policiales, al lugar en que hubiere de practicase la diligencia, o a su domicilio, en vehículos oficiales y durante el 
tiempo que permanezcan en dichas dependencias se les facilitará un local reservado para su exclusivo uso, convenientemente custodiado.

\section{Artículo 4:}

Cuantos funcionarios intervengan en los procesos a que se hace referencia en el art. 1 de esta Ley informarán a los denunciantes, testigos o peritos de los derechos que la presente disposición les reconoce y cuidarán de evitar que los mismos hayan de participar en ruedas de reconocimiento, o de responder a preguntas que, sin ser de interés para la averiguación de los hechos o de sus responsables, tengan por finalidad descubrir la identidad del denunciante, deponente o informante.

\section{Artículo 5:}

En las causas comprendidas en el art. 1 de esta Ley los Jueces o Tribunales únicamente solicitarán de los miembros de las Fuerzas y Cuerpos de Seguridad la identidad de sus fuentes de información cuando resulte absolutamente imprescindible para el esclarecimiento de los hechos o para la persecución de sus responsables. En tal caso, los confidentes gozarán de los mismos derechos que los otorgados a denunciantes, peritos o testigos por la presente

\section{Artículo 6:}

Primero.-Una vez abierto el juicio oral y durante las sesiones del mismo los denunciantes, testigos o peritos gozarán de todos los derechos que esta Ley otorga, sin que en ningún caso puedan ser citados al mismo ni facilitarse su identidad, sin su consentimiento.

Segundo.-Si cualquiera de las partes solicitase en su escrito de calificación provisional el conocimiento de la identidad de los denunciantes, testigo o peritos propuestos, cuya declaración o informe sea estimado pertinente, el Juez o Tribunal que haya de entender de la causa, en el mismo auto en el que declare la pertinencia de la prueba propuesta, previa constancia de su consentimiento, facilitará exclusivamente el nombre y los apellidos de los denunciantes, testigos y peritos, respetando las restantes garantías reconocidas a los mismos en esta Ley.

En tal caso, el plazo para la recusación de peritos a que se refiere el art. 662 de la Ley de Enjuiciamiento Criminal se computará a partir del momento en que se notifique a las partes la identidad de los mismos.

En los cinco días siguientes a la notificación a las partes de la filiación de los testigos, cualquiera de ellas podrá proponer nueva prueba tendente a acreditar alguna circunstancia que puede influir en el valor probatorio de su testimonio.

\section{Artículo 7:}

En los supuestos prevenidos en los arts. 424, 448, 449 y párrafo segundo del art. 467 de la Ley de Enjuiciamiento Criminal, el Juez Instructor, a petición de parte, hará constar en las diligencias únicamente el nombre y apellidos del denunciante, testigo o perito. 


\section{Artículo 8:}

Las declaraciones o informes de denunciantes, testigos o peritos que se hayan amparado en el anonimato durante la fase de instrucción, solamente podrán tener valor de prueba, a efectos de sentencia, si son ratificadas, en el acto del juicio oral, por quien las prestó.

\section{Artículo 9:}

Los acusados por hechos comprendidos en el apartado a) del art. 1 de la presente Ley, en la medida en que presten declaración contra su coreos, podrán acogerse a los beneficios del artículo siguiente y a los previstos en el art. 2 de esta Ley.

\section{Artículo 10:}

$\mathrm{Si}$ alguno de los denunciantes, testigos o peritos a que se refiere la presente Ley fuere detenido o reducido a prisión, habrá de ser custodiado en centros o establecimientos que no alberguen elementos terroristas, miembros de la banda armada, o grupos criminales organizados, sobre los cuales prestaron declaración aquellos.

\section{Artículo 11:}

El párrafo segundo del art. 367 del Código Penal quedará redactado del siguiente modo:

«Si de la revelación a que se refiere el párrafo anterior resultaren graves daños para la causa pública o para tercero, o consistiere en la divulgación de la identidad o domicilio, o de datos que pudieran facilitar su averiguación, de los denunciantes, testigos o peritos que hayan prestado declaración o informe en procesos penales incoados con motivo u ocasión de actos delictivos cometidos por elementos terroristas, personas integradas en bandas armadas o vinculadas de cualquier modo a las mismas, o por grupos criminales organizados, las penas serán las de prisión menor e inhabilitación especial.»

\section{Artículo 12:}

Las personas protegidas comprendidas dentro del ámbito de la presente Ley, así como, en su caso, su cónyuge o persona a quien se hallen ligados por análoga relación de afectividad, ascendientes, descendientes o hermanos que fuesen objeto de un ataque contra su vida, integridad, libertad o patrimonio como consecuencia directa de su denuncia, testimonio o informe, tendrán derecho a ser indemnizados por el Estado en la cuantía y modo que reglamentariamente se determine.

\section{DISPOSICIONES ADICIONALES}

Primera: La presente Ley tendrá el carácter de orgánica en su art. 11.

Segunda: El Gobierno, en el plazo de un año a partir de la publicación de la presente Ley, dictará las disposiciones reglamentarias que resulten necesarias para su ejecución. 


\section{DISPOSICION DEROGATORIA}

Quedan derogados cuantos preceptos se opongan a lo dispuesto en la presente Ley, en la medida en que contradigan sus previsiones.

\section{DISPOSICION FINAL}

Esta Ley entrará en vigor al día siguiente de su publicación en el Boletín Oficial del Estado.

Las líneas básicas de esta proposición de Ley, como se desprende de su texto y tal y como las expuso el Sr. Caballero Lasquibar ${ }^{10}$, al solicitar el voto favorable en el Senado para su toma en consideración, son sustancialmente las siguientes:

1. Todo el conjunto de la proposición se circunscribe a los delitos relativos a terrorismo, o los cometidos por bandas armadas o grupos criminales violentos organizados.

2. Se protege la seguridad de los denunciantes, testigos o peritos garantizando el secreto de su identidad frente a terceros en la fase policial y en la fase judicial instructora.

3. Se regulan medidas complementarias de protección a la reserva de la identidad tales como la protección policial durante el proceso y el tiempo que se estime pertinente tras su finalización, la provisión de medios económicos suficientes para cambiar de residencia o lugar de trabajo y, si fuera preciso, de una nueva identidad.

4. Estas medidas de protección que se garantizan en la fase policial y en la judicial de instrucción tienen algún límite una vez que se abre la fase de juicio oral, en razón del derecho del acusado a un proceso con todas las garantías, que debe poder conocer la identidad de las personas que han de ser utilizadas para articular una prueba procesal de cargo. En estos casos se añade un principio de voluntariedad en la participación del testigo en la fase del juicio oral que, de no comparecer, ve garantizada su reserva de identidad y su testimonio queda en la fase instructora como un elemento más para formar la investigación de los hechos y poder contribuir a la convicción del Juez, junto a las demás pruebas que se hayan acumulado.

Si en el juicio oral decide intervenir el denunciante, testigo o perito, será conocida su identidad, pero permanecerán el resto de medidas del programa de protección: la reserva de sus otros datos

10 Boletín Oficial de las Cortes Generales. Senado. Quinta Legislatura. Serie III A. Proposiciones de Ley del Senado. 6 octubre 1993, p. 139. 
personales, como la residencia, centro de trabajo, o su imagen física y las posibilidades de cambio de residencia o de identidad.

5. Se prevé la aplicación adecuada del programa a los miembros de los Cuerpos y Fuerzas de Seguridad del Estado y para sus fuentes de información, confidentes y co-reos declarantes en una causa. Para éstos últimos se establecen mandatos a fin de garantizar su seguridad en los centros penitenciarios en que sean ingresados.

6. Se extienden las medidas de protección, no sólo a los denunciantes, testigos y peritos, sino también a su círculo familiar.

7. La adecuada protección de las personas referidas exige que las mismas o, en su caso, sus más allegados parientes, tengan derecho a una indemnización por parte del Estado cuando hubieren sufrido un ataque a su vida, integridad personal o bien como consecuencia directa del testimonio prestado.

8. En consecuencia con el conjunto de medidas protectoras descrito se modifica el art. 367 del Código Penal, elevando sustancialmente la pena del delito de revelación del secreto para los funcionarios que no guarden la reserva de la identidad y datos personales garantizada en la proposición. En este punto, al tratarse de una modificación del Código Penal, la proposición ha de tener carácter de orgánica.

Con este conjunto de medidas protectoras se trata así de garantizar la participación ciudadana en el auxilio y colaboración con la Justicia, guardando los equilibrios precisos en cuanto a los intereses generales implicados y a los también garantizados derechos de los acusados a un juicio pleno de garantías.

\section{Tramitación parlamentaria}

La antedicha Proposición de Ley se publicaba en el Boletín Oficial de las Cortes Generales (Senado) del día 15 de septiembre de 1993, iniciándose con ello su tramitación parlamentaria.

No empezaba con buen pie la singladura por cuanto la Secretaría General Técnica del Ministerio de Justicia, en informe de fecha 5 de agosto de 1993, se había pronunciado en contra de su toma en consideración.

El 5 de octubre de 1993 se reunía el Senado para estudiar la toma en consideración de la Proposición de Ley. Tras hacer uso de la palabra en primer lugar el Senador Sr. Caballero Lasquibar (Partido Nacionalista Vasco) en defensa de la misma, se inició un turno de intervenciones de los diversos Grupos Parlamentarios. Tomaron parte en él los representan- 
tes de Convergencia y Unión, Coalición Canaria, Partido Popular y Partido Socialista Obrero Español.

En síntesis, los portavoces de los partidos no proponentes se mostraban de acuerdo con la iniciativa legislativa, si bien apuntaban la necesidad de introducir enmiendas técnicas a su articulado ${ }^{11}$.

Finalmente la Proposición de Ley fue tomada en consideración, remitiéndose su texto al Congreso de los Diputados para su tramitación parlamentaria.

Formularon enmiendas al articulado del texto el Partido Nacionalista Vasco y el Partido Socialista Obrero Español (conjuntamente) ${ }^{12}$, Grupo Mixto-Unión Valenciana, Coalición Canaria, Partido Popular y Convergencia y Unión ${ }^{13}$.

De todas las enmiendas presentadas nos limitaremos a exponer las formuladas conjuntamente por el PNV y PSOE, por la incidencia que tendrían posteriormente en el texto definitivo de la Ley. Ambas fuerzas políticas proponían:

A) La supresión de los arts. 4, 5, 7, 8, 9, 10, 11, 12 y disposición adicional primera.

B) Dar una nueva redacción a los arts. 1, 2, 3 y 6, que quedarían redactados del siguiente modo:

\section{Artículo 1:}

1. Las disposiciones de esta Ley son aplicables a quienes en calidad de testigos o peritos intervengan en procesos penales.

2. Para que vengan en aplicación las disposiciones de la presente Ley será necesario que la autoridad judicial aprecie racionalmente un peligro grave para la persona, libertad o bienes de quien pretenda ampararse en ella, su cónyuge o persona a quien se halle ligado por análoga relación de afectividad o sus ascendientes, descendientes o hermanos.

\section{Artículo 2:}

1. Apreciada la circunstancia prevista en el artículo anterior, el Juez Instructor acordará motivadamente, de oficio o a instancia de parte, cuando lo estime necesario en atención al grado de riesgo o peligro, las medidas necesarias para preservar la identidad de los testigos y peritos, su domicilio, pro-

11 Las intervenciones concretas de cada Grupo Parlamentario pueden ser examinadas en el Boletín Oficial de las Cortes Generales (Senado). 6 octubre 1993, pp. 138 y ss.

12 Boletín Oficial de las Cortes Generales. Congreso de los Diputados. Serie B. Proposiciones de Ley. 15 abril 1994, pp. 31 y ss.

13 Para un conocimiento completo de las enmiendas formuladas, véase: Boletín Oficial de las Cortes Generales. Congreso de los Diputados. Serie B. Proposiciones de Ley. 28 marzo 1994, pp. 17 y ss.

14 Boletín Oficial de las Cortes Generales. Congreso de los Diputados. Serie B. Proposiciones de Ley. 11 octubre 1994, pp. 47 y ss. 
fesión y lugar de trabajo, sin perjuicio de la acción de contradicción que asiste a la defensa del procesado, pudiendo adoptar las siguientes decisiones:

a) Que no consten en las diligencias que se practiquen su nombre, apellidos, domicilio, lugar de trabajo y profesión, ni cualquier otro dato que pudieran servir para la identificación de los mismos, pudiéndose utilizar para ésta un número o cualquier otra clave.

b) Que comparezca para la práctica de cualquier diligencia utilizando cualquier procedimiento que imposibilite su identificación visual normal.

c) Que para la práctica de cualquier diligencia se fije como domicilio, a efectos de citaciones, o notificaciones, la sede del órgano judicial interviniente, el cual las hará llegar reservadamente a su destinatario.

\section{Artículo 3:}

1. Los miembros y las Fuerzas y Cuerpos de Seguridad, el Ministerio Fiscal y la Autoridad Judicial, cuidarán de evitar que a los testigos o peritos se les hagan fotografías o se tome su imagen por cualquier otro procedimiento, debiéndose proceder a retirar el material fotográfico, cinematográfico, videográfico o de cualquier otro tipo a quien contraviniere esta prohibición. Dicho material será devuelto a su titular una vez comprobado que no existen vestigios de tomas en los que aparezcan los testigos o peritos de forma tal que pudieran ser identificados.

2. A instancia del Ministerio Fiscal y para todo el proceso, se brindará a los testigos y peritos, en su caso, protección policial. En casos excepcionales podrán facilitárseles documentos de una nueva identidad y medios económicos para cambiar su residencia o lugar de trabajo. Los testigos y peritos podrán solicitar ser conducidos a las dependencias judiciales, al lugar donde hubiere de practicarse alguna diligencia o a su domicilio en vehículos oficiales y durante el tiempo que permanezcan en dichas dependencias se les facilitará un local reservado para su exclusivo uso, convenientemente custodiado.

\section{Artículo 6:}

1. En el auto en que se acuerde la apertura del juicio oral, el órgano judicial competente se pronunciará motivadamente sobre la procedencia de mantener, modular o suprimir todas o algunas de las medidas de protección de los testigos y peritos adoptadas por el Juez de Instrucción, así como si procede la adopción de otras nuevas, previa ponderación de los bienes jurídicos constitucionalmente protegidos, de los derechos fundamentales en conflicto y de las circunstancias concurrentes en los testigos y peritos en relación con el proceso penal de que se trate.

2. Las medidas adoptadas por el Juez de Instrucción podrán ser objeto del recurso de apelación. Hasta tanto se resuelva el citado recurso no se realizará actuación alguna que pueda enervar la eficacia posterior de la aplicación de las garantías que esta Ley contempla.

3. Sin perjuicio de lo anterior, los Letrados de la defensa y acusación, en su caso, podrán, motivando las razones de hacerlo en este trámite, antes 
de formular sus escritos de acusación, defensa o conclusiones provisionales, solicitar la identidad de los peritos o testigos. De igual forma, lo podrán pedir, a la vista de las pruebas solicitadas y admitidas por las otras partes.

A la vista de dichas alegaciones el Juez motivadamente resolverá si procede o no dar los datos de la identificación de aquellos.

4. Las declaraciones o informes de los testigos y peritos que hayan sido objeto de protección en aplicación de esta Ley durante la fase de instrucción sumarial, solamente podrán tener valor de prueba, a efectos de sentencia, si son ratificadas en el acto del juicio oral en la forma prescrita en la Ley de Enjuiciamiento Criminal por quien la prestó. Si se consideraran de imposible reproducción a efectos del art. 730 de la Ley de Enjuiciamiento Criminal, habrán de ser ratificadas mediante lectura literal a fin de que puedan ser sometidas a contradicción por parte de la defensa.

Pasadas las enmiendas a estudio de la Comisión de Justicia e Interior, se elevó por ésta dictamen del siguiente tenor:

Primero.-Mantener los arts. 1, 2 y 3 tal y como proponían PNV y PSOE en sus enmiendas conjuntas.

Segundo.-Dar una nueva redacción al art. 4, que quedaría redactado así:

Artículo 4.

1. En el auto en que se acuerde la apertura del juicio oral, el órgano judicial competente se pronunciará motivadamente sobre la procedencia de mantener, modular o suprimir todas o algunas de las medidas de protección de los testigos o peritos adoptadas por el Juez de Instrucción, así como si procede la adopción de otras nuevas, previa ponderación de los bienes jurídicos constitucionalmente protegidos, de los derechos fundamentales en conflicto y de las circunstancias concurrentes en los testigos y peritos en relación con el proceso penal de que se trate.

2. Las medidas adoptadas podrán ser objeto del recurso de apelación en ambos efectos.

3. Sin perjuicio de lo anterior, si cualquiera de las partes solicitase motivadamente en su escrito de calificación provisional, acusación o defensa, el conocimiento de la identidad de los testigos o peritos propuestos, cuya declaración o informe sea estimado pertinente, el Juez o Tribunal que haya de entender la causa, en el mismo auto en el que declare la pertinencia de la prueba propuesta, podrá facilitar motivadamente y a la vista de las alegaciones hechas por las partes el nombre y los apellidos de los testigos y peritos, respetando las restantes garantías reconocidas a los mismos en esta Ley.

En tal caso, el plazo para la recusación de peritos a que se refiere el art. 662 de la Ley de Enjuiciamiento Criminal se computará a partir del momento en que se notifique a las partes la identidad de los mismos.

En los cinco días siguientes a la notificación a las partes de la filiación de los testigos, cualquiera de ellos podrá proponer nueva prueba ten- 
dente a acreditar alguna circunstancia que pueda influir en el valor probatorio de su testimonio.

4. De igual forma, las partes podrán hacer uso del derecho previsto en el apartado anterior, a la vista de las pruebas solicitadas por las otras partes y admitidas por el órgano judicial, en el plazo previsto para la interposición de recurso de reforma y apelación.

5. Las declaraciones o informes de los testigos y peritos que hayan sido objeto de protección en aplicación de esta Ley durante la fase de instrucción sumarial, solamente podrán tener valor de prueba, a efectos de sentencia, si son ratificados en el acto del juicio oral en la forma prescrita en la Ley de Enjuiciamiento Criminal por quien los prestó. Si se consideraran de imposible reproducción a efectos del art. 730 de la Ley de Enjuiciamiento Criminal, habrán de ser ratificados mediante lectura literal a fin de que puedan ser sometidos a contradicción de las partes.

El Pleno del Congreso de los Diputados, reunido en Sesión de 27 de octubre de 1994 debatía el texto remitido por la Comisión de Justicia e Interior y, tras introducir una nueva enmienda al polémico art. 4, aprobaba la Ley de Protección a Testigos y Peritos, con el apoyo de todos los Grupos Parlamentarios presentes.

Remitido el Texto aprobado por el Congreso al Senado, en este último se le formularon por diversos Grupos Parlamentarios un total de 21 enmiendas. La Ponencia designada al efecto emitió su informe el 22 de noviembre de 1994, incorporando al texto, por unanimidad, 15 de ellas. Quedó formulado, para su debate, un voto particular por el Grupo Parlamentario Popular (enmiendas 4 y 5); dichas enmiendas del precitado Grupo fueron rechazadas por el Pleno del Senado en su Sesión de 30 de noviembre de 1994, votándose el Texto de la Proposición de Ley, tal y como venía informado por la ponencia, con el siguiente resultado: votos a favor 229; votos en contra 1.

En el Boletín Oficial de las Cortes Generales (Senado) de fecha 7 de diciembre de 1994 se publicaba el Texto aprobado por el Senado, acordándose su remisión de nuevo al Congreso, a los efectos previstos en el art. 90-2 de la Constitución Española.

Finalmente, el día 23 de diciembre de 1994 se aprobaba definitivamente el Texto de la «Ley Orgánica de Protección a Testigos y Peritos en causas criminales», que aparecería publicada en el Boletín Oficial del Estado de fecha 24-12-1994, y cuyo contenido es del siguiente tenor:

\section{EXPOSICION DE MOTIVOS}

La experiencia diaria pone de manifiesto en algunos casos las reticencias de los ciudadanos a colaborar con la Policía Judicial y con la Administración de Justicia en determinadas causas penales ante el temor a sufrir represalias. 
Ello conlleva, con frecuencia, que no se pueda contar con testimonios y pruebas muy valiosos en estos procesos.

Ante esta situación, el Legislador debe proceder a dictar normas que resulten eficaces en la salvaguarda de quienes, como testigos o peritos, deben cumplir con el deber constitucional de colaboración con la justicia.

De no hacerlo así, podrían encontrarse motivos que comportasen retraimientos e inhibiciones por parte de posibles testigos o peritos no deseables en un Estado de derecho, con el añadido de verse perjudicada la recta aplicación del ordenamiento jurídico-penal y facilitada, en su caso, la impunidad de los presuntos culpables.

Es obvio, sin embargo, que las garantías arbitradas en favor de los testigos y peritos no pueden gozar de un carácter absoluto e ilimitado, es decir, no pueden violar los principios del proceso penal. De ahí que la presente Ley tenga como norte hacer posible el necesario equilibrio entre el derecho a un proceso con todas las garantías y la tutela de derechos fundamentales inherentes a los testigos y peritos y a sus familiares.

El sistema implantado confiere al Juez o Tribunal la apreciación racional del grado de riesgo o peligro y la aplicación de todas o alguna de las medidas legales de protección que considere necesarias, previa ponderación, a la luz del proceso, de los distintos bienes jurídicos constitucionalmente protegidos; medidas que, en el marco del derecho de defensa, serán susceptibles de recurso en ambos efectos.

El propósito protector al que responde la Ley no es, por lo demás, exclusivo de nuestro País. De acuerdo con directrices señaladas por el derecho comparado, se ha entendido ser imperiosa e indeclinable la promulgación de las normas precisas para hacer realidad aquel propósito de protección de testigos y peritos que, además, ha sido admitido por el Tribunal Europeo de Derechos Humanos, cuyo principio general se hace también patente en la resolución 827/1993, de 25 de mayo, del Consejo de Seguridad de las Naciones Unidas, concerniente a la antigua Yugoslavia.

El contenido de la Ley es breve. Junto a su ámbito de aplicación, regulado en el art. 1, y las medidas protectoras y garantías del justiciable recogidos en los arts. 2 y 3 , contiene el art. 4 y último una serie de medidas complementarias de protección que habrán de aplicar, cada uno en su esfera, los miembros de las Fuerzas y Cuerpos de Seguridad del Estado, el Ministerio Fiscal y la Autoridad Judicial.

\section{Artículo 1:}

1. Las medidas de protección previstas en esta Ley son aplicables a quienes en calidad de testigos o peritos intervengan en procesos penales.

2. Para que sean de aplicación las disposiciones de la presente Ley será necesario que la autoridad judicial aprecie racionalmente un peligro grave para la persona, libertad o bienes de quien pretenda ampararse en ella, su cónyuge o persona a quien se halle ligado por análoga relación de afectividad o sus ascendientes, descendientes o hermanos. 


\section{Artículo 2:}

Apreciada la circunstancia prevista en el artículo anterior, el Juez Instructor acordará motivadamente, de oficio o a instancia de parte, cuando lo estime necesario en atención al grado de riesgo o peligro, las medidas necesarias para preservar la identidad de los testigos y peritos, su domicilio, profesión y lugar de trabajo, sin perjuicio de la acción de contradicción que asiste a la defensa del procesado, pudiendo adoptar las siguientes decisiones:

a) Que no consten en las diligencias que se practiquen su nombre, apellidos, domicilio, lugar de trabajo y profesión, ni cualquier otro dato que pudiera servir para la identificación de los mismos, pudiéndose utilizar para ésta un número o cualquier otra clave.

b) Que comparezcan para la práctica de cualquier diligencia utilizando cualquier procedimiento que imposibilite su identificación visual normal.

c) Que se fije como domicilio, a efectos de citaciones y notificaciones, la sede del órgano judicial interviniente, el cual las hará llegar reservadamente a su destinatario.

\section{Artículo 3:}

1. Los miembros de las Fuerzas y Cuerpos de Seguridad, el Ministerio Fiscal y la Autoridad Judicial cuidarán de evitar que a los testigos o peritos se les hagan fotografías o se tome imagen por cualquier otro procedimiento, debiéndose proceder a retirar el material fotográfico, cinematográfico, videográfico o de cualquier otro tipo a quien contraviniere esta prohibición. Dicho material será devuelto a su titular una vez comprobado que no existen vestigios de tomas en las que aparezcan los testigos o peritos de forma tal que pudieran ser identificados.

2. A instancia del Ministerio Fiscal y para todo el proceso, o si, una vez finalizado éste, se mantuviera la circunstancia de peligro grave prevista en el art. 1-2 de esta Ley, se brindará a los testigos y peritos, en su caso, protección policial. En casos excepcionales podrán facilitárseles documentos de una nueva identidad y medios económicos para cambiar su residencia o lugar de trabajo. Los testigos y peritos podrán solicitar ser conducidos a las dependencias judiciales, al lugar donde hubiere de practicarse alguna diligencia o a su domicilio en vehículos oficiales y durante el tiempo que permanezcan en dichas dependencias se les facilitará un local reservado para su uso exclusivo, convenientemente custodiado.

\section{Artículo 4:}

1. Recibidas las actuaciones, el órgano judicial competente para el enjuiciamiento de los hechos se pronunciará motivadamente sobre la procedencia de mantener, modificar o suprimir todas o algunas de las medidas de protección de los testigos y peritos adoptadas por el Juez de Instrucción, así como si procede la adopción de otras nuevas, previa ponderación de los bienes jurídicos constitucionalmente protegidos, de los derechos fundamentales en conflicto y de las circunstancias concurrentes en los testigos y peritos en relación con el proceso penal de que se trate. 
2. Las medidas adoptadas podrán ser objeto de recurso de reforma o súplica.

3. Sin perjuicio de lo anterior, si cualquiera de las partes solicitase motivadamente en su escrito de calificación provisional, acusación o defensa, el conocimiento de la identidad de los testigos o peritos propuestos, cuya declaración o informe sea estimado pertinente, el Juez o Tribunal que haya de entender la causa, en el mismo auto en el que declare la pertinencia de la prueba propuesta, deberá facilitar el nombre y los apellidos de los testigos y peritos, respetando las restantes garantías reconocidas a los mismos en esta Ley.

En tal caso, el plazo para la recusación de peritos a que se refiere el art. 662 de la Ley de Enjuiciamiento Criminal se computará a partir del momento en que se notifique a las partes la identidad de los mismos.

En los cinco días siguientes a la notificación a las partes de la identidad de los testigos, cualquiera de ellas podrá proponer nueva prueba tendente a acreditar alguna circunstancia que pueda influir en el valor probatorio de su testimonio.

4. De igual forma, las partes podrán hacer uso del derecho previsto en el apartado anterior, a la vista de las pruebas solicitadas por las otras partes y admitidas por el órgano judicial, en el plazo previsto para la interposición de recurso de reforma y apelación.

5. Las declaraciones o informes de los testigos y peritos que hayan sido objeto de protección en aplicación de esta Ley durante la fase de instrucción, solamente podrán tener valor de prueba, a efectos de sentencia, si son ratificados en el acto del juicio oral en la forma prescrita en la Ley de Enjuiciamiento Criminal por quien los prestó. Si se consideraran de imposible reproducción, a efectos del art. 730 de la Ley de Enjuiciamiento Criminal, habrán de ser ratificados mediante lectura literal a fin de que puedan ser sometidos a contradicción por las partes.

\section{DISPOSICION ADICIONAL PRIMERA:}

El art. 3-2 de esta Ley tendrá el carácter de Ley ordinaria.

\section{DISPOSICION ADICIONAL SEGUNDA:}

El Gobierno, en el plazo de un año a partir de la publicación de la presente Ley, dictará las disposiciones reglamentarias que resulten necesarias para su ejecución.

\section{DISPOSICION DEROGATORIA UNICA:}

Quedan derogados cuantos preceptos se opongan a lo dispuesto en la presente Ley.

\section{DISPOSICION FINAL UNICA:}

Esta Ley entrará en vigor al día siguiente de su publicación en el Boletín Oficial del Estado. 


\section{Análisis del texto legal}

Diferencias fundamentales entre la proposición de Ley y el texto en vigor

En una primera aproximación al tema, lo primero que se advierte es la existencia de algunas diferencias importantes entre la proposición de Ley y el texto aprobado. Este último amplía el ámbito de la proposición al no establecer restricciones en orden a los procesos en que puede venir en aplicación. Por contra, la proposición de ley contemplaba dos aspectos que no han sido incorporados al texto legal:

1. La cobertura de la protección, que se extendía, en cierta medida, a los agentes de las Fuerzas y Cuerpos de Seguridad y a los co-reos «arrepentidos», bajo determinadas circunstancias.

2. El establecimiento de un régimen indemnizatorio en favor de los sujetos protegidos y sus más próximos allegados, cuando sufrieren un daño con motivo u ocasión de su cooperación con la Administración de Justicia. Cuesta trabajo entender esta renuencia estatal a indemnizar a quien sufre un perjuicio por contribuir a una causa pública.

\section{Ambito procesal}

Se desprende del art. 1-1 de la Ley que sus disposiciones serán aplicables en cualquier tipo de proceso penal, siempre y cuando se cumplan las condiciones exigidas en el párrafo segundo de dicho precepto. No existe, pues, limitación «ratione materiae». Ello implica que se hallan comprendidos tanto los procesos por delito o falta, corresponda su enjuiciamiento a la Jurisdicción Criminal ordinaria, a la Militar o a los Jueces de menores.

\section{Personas protegidas}

El art. 1-1 de la Ley circunscribe su radio de acción protector exclusivamente a quienes intervinieren en una causa penal en calidad de testigos o peritos; ello implica que no podrá acogerse a las medidas protectoras - siquiera estrictamente policiales y preventivas- el coinculpado «arrepentido».

Cuando en una ocasión tan reciente como la popularmente conocida como «Operación Nécora» se ha hecho patente la necesidad de brindar protección policial a dos arrepentidos, no se comprende que la Ley se haya «olvidado» de ellos.

Ciertamente que el «arrepentido» no podría beneficiarse del testimonio anónimo, pero ninguna dificultad hubiera existido en permitirles aco- 
gerse a las medidas protectoras establecidas en el apartado a) del art. 2 y en el párrafo segundo del art. 3.

La ausencia de toda referencia a los miembros de las Fuerzas y Cuerpos de Seguridad como titulares de un derecho de protección no plantea problemas cuando los mismos actúen en calidad de testigos o peritos, ya que en tal caso podrán ampararse en las disposiciones protectoras previstas en la Ley.

Sin embargo el problema se agudiza cuando los agentes de la autoridad intervengan en el proceso en calidad de querellados; en tal caso quedan excluidos de la protección específica prevista en el texto legal, cosa no del todo lógica, al menos mientras no se aprecie en su conducta un indicio racional de criminalidad.

El Legislador no ha sido sensible a un problema vivido con particular agudeza en el País Vasco: la utilización de la denuncia o de la querella sistemática por sectores radicales contra los miembros de las Fuerzas de Seguridad, entre otras cosas para «identificarlos» como posibles blancos o, cuando menos, para atemorizarlos ${ }^{15}$.

No contiene referencia alguna la Ley a los «confidentes», quizás por entender que éstos gozan de una particular y suficiente protección a través de lo dispuesto en el art. 5-5 de la Ley de Fuerzas y Cuerpos de Seguridad del Estado. Obvio es decir, sin embargo, que, en aquellos supuestos excepcionales en que la autoridad judicial considere necesaria la comparecencia del confidente para declarar como testigo, aquél podría gozar de los beneficios que la Ley otorga a estos últimos.

\section{Requisitos para otorgar la protección}

Previene el art. 1-2 que:

«Para que sean de aplicación las disposiciones de la presente Ley será necesario que la autoridad judicial aprecie racionalmente un peligro grave para la persona, libertad o bienes de quien pretenda ampararse en ella, su cónyuge o persona a quien se halle ligado por análoga relación de afectividad o sus ascendientes, descendientes o hermanos.»

Partiendo de la base de que esta Ley establece un régimen procesal excepcional, que en alguna medida puede incidir en las garantías procesales del justiciable, es de todo punto razonable la doble exigencia de que:

15 Esta fue, sin duda, la razón de ser del art. 1-B de la Proposición de Ley del Partido Nacionalista Vasco. 
a) Exista un peligro grave, $y$

b) Que como tal sea apreciado por la autoridad judicial, ponderando en cada caso los bienes en conflicto.

En consecuencia, la procedencia o no de otorgar las medidas protectoras queda garantizada por la intervención del Poder Judicial, para evitar abusos y corruptelas. Bien entendido que contra tal decisión judicial, concediendo o denegando la protección solicitada, cabrán los recursos pertinentes.

Cuestión distinta es si la adopción de todas las medidas de protección requieren un previo pronunciamiento judicial.

Para dar contestación a esta pregunta es preciso reparar en un detalle: aunque no lo diga expresamente, la Ley prevé dos grupos de medidas protectoras sustancialmente distintas: las que podrían denominarse procesales o judiciales, contempladas en los apartados a), b) y c). del art. 2 y las que cabría calificar de extraprocesales o gubernativas, que vendrían recogidas en el art. 3 .

Tratándose de medidas de protección procesales (art. 2) la Ley no deja lugar a dudas: es a la autoridad judicial a quien corresponde acordarlas.

Por el contrario, las medidas de protección extraprocesales contempladas en el art. 3 no precisan de un acuerdo expreso de la autoridad judicial. Obsérvese a este respecto que la medida cautelar descrita en el art. 3-1 (interdicción de toma de imágenes) puede ser adoptada o exigida por el Ministerio Fiscal, e incluso por las propias Fuerzas y Cuerpos de Seguridad.

Por lo que respecta al elenco de medidas cautelares tipificadas en el art. 3-2, la Ley admite que se apliquen «a instancia del Ministerio Fiscal», y por su propia naturaleza más parece materia gubernativa que judicial.

Nuevo problema a resolver es quiénes se encuentran legitimados para solicitar la adopción de las medidas de protección enumeradas en el art. 2. El precepto en cuestión señala que tales medidas podrán acordarse «de oficio o a instancia de parte».

La cuestión a dilucidar es si cuando la Ley habla de «parte» lo hace en sentido formal (acusación-defensa) o ha de darse a este término un sentido más amplio. Dicho más claramente, ¿goza de legitimación para solicitar la adopción de las medidas protectoras el testigo o perito que ha de prestar declaración o rendir informe? La respuesta es afirmativa. Téngase en cuenta a este respecto que, a tenor de lo dispuesto en el art. 270 de la Ley Orgánica del Poder Judicial, las resoluciones judiciales habrán de notificarse «a quienes se refieran o puedan causar perjuicio», tesis 
avalada por la sentencia del Tribunal Constitucional de fecha 15 de noviembre de 1990 (fundamento jurídico octavo).

No podía ser de otro modo por cuanto el mayor interesado en impetrar la protección judicial lo es precisamente el perito o testigo llamado a declarar en la causa.

El modo en que se acuerden esas medidas protectoras de carácter judicial lo será a medio de auto (art. 141 de la Ley de Enjuiciamiento Criminal), en el cual el Juzgador habrá de pronunciarse motivadamente sobre los siguientes extremos:

1. La existencia o no de un peligro grave, en los términos contemplados en el art. 1 de la Ley, ponderando las circunstancias concurrentes y los derechos en conflicto.

2. Las medidas concretas de protección que hayan de adoptarse, o, en su caso, la improcedencia de las mismas y,

3. La persona o personas que pueden ampararse en ellas, designadas por un número o clave cuando se acuerde preservar su identidad.

El auto habrá de ser notificado a las partes en sentido formal y a los testigos o peritos afectados por el mismo, y contra dicha resolución podrán todos los anteriores entablar los recursos pertinentes.

Queda, sin embargo, por resolver un problema importante: del tenor literal de los arts. 1 y 2 cabría deducir que sólo la autoridad judicial está capacitada para otorgar o denegar las medidas protectoras señaladas en el art. 2. ¿Qué hacer entonces con los testigos y peritos que declaren antes de que se abra el proceso judicial propiamente dicho? (atestado policial; diligencias informativas incoadas a instancia del Ministerio Fiscal).

Como sería un contrasentido e iría contra la «voluntas legis» que esos testigos o peritos en sede policial previa hubieran de identificarse para a continuación deducir en el proceso judicial una solicitud de anonimato ya imposible, no caben más que dos soluciones:

1. Entender que, con carácter cautelar y en tanto no se aperturen diligencias judiciales, la policía o el Ministerio Fiscal están facultados para otorgar al testigo o perito las medidas de protección contempladas en la Ley, a los testigos y peritos que declaren en el atestado policial inicial o en las diligencias informativas abiertas por el Ministerio Fiscal.

2. Alternativamente: que en tales casos se solicitase del Juzgado de Instrucción de guardia la adopción de las medidas cautelares.

Razones de agilidad y rapidez aconsejan adoptar la primera solución, sin que ello suponga perjuicio para el justiciable toda vez que, remitido 
el atestado al Juez competente, éste decidirá si procede o no ratificar las medidas cautelares previamente acordadas.

Y para finalizar con este apartado es preciso incidir en una cuestión de primera magnitud: ¿vulneran el art. 24 de la Constitución Española (derecho a un proceso con todas las garantías) las previsiones contenidas en los apartados a) y b) del art. 2? Dicho precepto permite, durante la fase de instrucción de la causa, la figura del testigo anónimo y además oculto.

Para dar respuesta a esta pregunta es preciso poner de relieve:

1. Que para acordar ese régimen excepcional es precisa una resolución judicial motivada.

2. Que el anonimato del testigo o perito lo es frente al acusado, pero no para el Juez Instructor, que habrá de conocer su verdadera identidad.

3. Que el testigo o perito anónimo deberán declarar ante el Juez Instructor, con lo que éste podrá tener una impresión personal y directa acerca de su credibilidad, y

4. Que el hecho que durante la instrucción de la causa el testigo o perito sea anónimo y no pueda ser reconocido visualmente, no impide que la defensa pueda interrogarlo (art. 1: «sin perjuicio del derecho de contradicción que asiste a la defensa»).

Si a ello se añade que el Tribunal Europeo de Derechos Humanos ha declarado en reiteradas sentencias (casos Kostovski, Windisch y Lüdi) que el testimonio anónimo en la fase de instrucción no vulnera el art. 6 del Convenio Europeo para la Protección de los Derechos Humanos, se llega a la conclusión de que el art. 2 de la Ley se ajusta a los dictados del art. 24 de la Constitución Española; porque, si bien el Tribunal Constitucional Español ha establecido ya en dos ocasiones que «la imposibilidad de contradicción y el total anonimato» de los testigos de cargo supondría violación de precepto constitucional, ello lo ha sido en relación con la declaración de dichos testigos en el acto del juicio oral.

\section{Medidas protectoras}

Como ya quedó apuntado en el epígrafe precedente, aun sin denominarlas de este modo la Ley prevé dos clases distintas de medidas protectoras: las judiciales o procesales (art. 2) y las extraprocesales, policiales o gubernativas (art. 3).

El testigo o perito protegido por las medidas judiciales gozará de los siguientes beneficios procesales: 
a) Que no consten en las diligencias que se practiquen su nombre, apellidos, domicilio, y lugar de trabajo o profesión, ni cualquier otro dato que pudiera servir para la identificación de los mismos, pudiéndose utilizar para ésta un número o cualquier otra clave.

b) Que comparezca para la práctica de cualquier diligencia utilizando cualquier procedimiento que imposibilite su identificación visual normal.

c) Que para la práctica de cualquier diligencia se fije como domicilio a efectos de citaciones y notificaciones, la sede del órgano judicial interviniente, el cual las hará llegar reservadamente a su destinatario.

Las medidas protectoras extrajudiciales, policiales o gubernativas se recogen en el art. 3, a cuyo tenor:

1. Los miembros de las Fuerzas y Cuerpos de Seguridad, el Ministerio Fiscal y la autoridad judicial, cuidarán de evitar que a los testigos o peritos se les hagan fotografías o se tome su imagen por cualquier otro procedimiento, debiéndose proceder a retirar el material fotográfico, cinematográfico, videográfico o de cualquier otro tipo a quien contraviniere esta prohibición. Dicho material será devuelto a su titular una vez comprobado que no existen vestigios de tomas en las que aparezcan los testigos o peritos de forma tal que pudieran ser identificados.

2. A instancia del Ministerio Fiscal y para todo el proceso, o si, una vez finalizado éste, se mantuviera la circunstancia de peligro grave prevista en el art. 1-2 de esta Ley se brindará a los testigos y peritos, en su caso, protección policial. En casos excepcionales podrán facilitárseles documentos de una nueva identidad y medios económicos para cambiar su residencia o lugar de trabajo. Los testigos y peritos podrán solicitar ser conducidos a las dependencias judiciales, al lugar donde hubiere de practicarse alguna diligencia o a su domicilio en vehículos oficiales y durante el tiempo que permanezcan en dichas dependencias se les facilitará un local reservado para su uso exclusivo, convenientemente custodiado.

Lo primero que es preciso advertir es que el otorgamiento de las medidas protectoras señaladas en el art. 2 no conlleva necesariamente que a la persona protegida haya de facilitársele también todas las medidas gubernativas señaladas en el art. 3. Así, puede concederse a un testigo sumarial el privilegio del anonimato pero estimarse que no precisa de protección policial o de un cambio de identidad, o de una asignación económica para mudar de residencia. 
En sentido opuesto cabe también la posibilidad de que no se acuerde el anonimato sumarial pero, como contrapartida, se brinde protección policial al testigo o perito, o se le otorgue otro tipo de protección prevista en el art. 3.

También parece obvio que las medidas protectoras podrán modificarse a lo largo del proceso, en consonancia con lo que las circunstancias demanden.

Por lo que respecta a la «protección policial» contemplada en el art. 3-2, tras una enmienda introducida por el Senado al texto aprobado por el Congreso, ésta podrá extenderse no solamente al proceso sino incluso una vez finalizado éste, si perdurase un peligro grave para la persona protegida.

Aunque la Ley sólo hace referencia a la posibilidad de facilitar «medios económicos» para un eventual cambio de residencia, no existe dificultad alguna en que sea la propia Administración quien ponga a disposición del testigo o perito amenazado una nueva residencia.

Más sencillo resultará el cambio de lugar de trabajo, cuando quien lo solicite sea un funcionario público que puede ejercer indistintamente las actividades propias de su cargo en una u otra población (piénsese, por ejemplo, en policías).

Especial mención merece el «cambio de identidad» autorizado, aunque con carácter excepcional, por el art. 3-2. Esta cautela extrema habrá de regularse con particular cuidado para evitar que el favorecido por tal medida pueda utilizarla como medio para eludir el cumplimiento de obligaciones legales de cualquier tipo (civiles, penales, etc.) contraídas con anterioridad. Las disposiciones reglamentarias que, al amparo de la disposición adicional segunda se dicten en el futuro, deberán regular expresamente esta cuestión exigiendo, por ejemplo, que antes de proceder a un cambio de identidad la persona haga una declaración de obligaciones precedentemente adquiridas y previniendo que la omisión maliciosa cometida en tal declaración o el uso de la nueva identidad con el propósito de perjudicar a terceros, dará lugar a la revocación de la medida.

Finalmente es preciso hacer referencia al caso de que el testigo o perito protegido por el anonimato utilizase éste para cometer un delito de acusación y denuncia falsa, o de falso testimonio. En tal caso la autoridad judicial debería necesariamente alzar el anonimato:

1. Porque la ley se ha dictado para proteger a ciudadanos decentes, no para favorecer las falsas delaciones, $y$

2. Porque el perjudicado por tales delitos tendría derecho a ejercer las acciones penales que tuviese por conveniente contra el autor de los mismos. 


\section{Las medidas de protección en el juicio oral}

Es obvio que el régimen de las medidas protectoras no puede ser igual en la fase de sumario que en el juicio oral; en la primera de ellas, siguiendo el criterio marcado por el Tribunal Europeo de Derechos Humanos, cabe un reforzamiento de las medidas de protección que no es posible mantener en todos sus términos en la fase de plenario, por ser la instrucción preliminar una mera preparación de las pruebas a utilizar en el juicio oral, momento solemne en el que habrán de reproducirse ante el Tribunal de la causa para que puedan cobrar valor como instrumento de convicción.

Ello conlleva que cualquier sistema que supusiese una grave limitación al derecho de la defensa del acusado correría el riesgo de ser reputado contrario al principio de igualdad de armas y al de prohibición de indefensión.

De ahí que la Ley regule de distinta forma las medidas protectoras en ambas fases del proceso penal, sin por ello perder de vista la ponderación de los bienes en conflicto como elemento que ha de presidir la actuación de los Tribunales en unas causas en que, junto al legítimo ejercicio del derecho de defensa, es también necesario tutelar el no menos legítimo derecho del ciudadano a que no se le exija correr riesgos graves por cumplir con un deber de testificar.

Siguiendo estas premisas la Ley regula las medidas de protección durante el juicio oral en su art. 4, sin duda alguna el más debatido durante la tramitación parlamentaria, hasta el punto de haber sufrido cuatro modificaciones desde la inicial proposición de ley hasta el texto vigente.

Tal «ajetreo» legislativo ha dado lugar, entre otras cosas, a que el precepto en cuestión adolezca de ciertas imperfecciones técnicas que habrán de ser salvadas por el intérprete acudiendo a las disposiciones generales de la Ley de Enjuiciamiento Criminal. Así, el párrafo primero del art. 4 establece que:

«Recibidas las actuaciones, el órgano judicial competente para el enjuiciamiento de los hechos se pronunciará motivadamente sobre la procedencia de mantener, modificar o suprimir todas o algunas de las medidas de protección de los testigos y peritos adoptadas por el Juez de Instrucción, así como si procede la adopción de otras nuevas, previa ponderación de los bienes jurídicos constitucionalmente protegidos, de los derechos fundamentales en conflicto y de las circunstancias concurrentes en los testigos y peritos en relación con el proceso penal de que se trate.» 
Añade a continuación el núm. 2 de este precepto que:

«Las medidas adoptadas podrán ser objeto de recurso de reforma o súplica», en función de que sea el Juez de lo Penal o la Audiencia Provincial quien adopte dichas medidas que, por supuesto, habrán de serlo mediante auto motivado.

Una vez más, en esta ocasión, hubo de ser el Senado quien se encargase, por vía de enmiendas, de subsanar algunos defectos de técnica legislativa que se advertían en el texto aprobado por el Congreso.

Es de resaltar únicamente que, mientras contra el auto adoptando o denegando la adopción de medidas protectoras dictado por el Juez de Instrucción caben los recursos de reforma y queja, contra el mismo auto dictado por el Juez de lo Penal sólo cabe el de reforma.

En cuanto a las medidas de protección susceptibles de ser adoptadas durante el juicio oral cabe señalar que el órgano encargado del enjuiciamiento puede otorgar todas las previstas en la Ley, con una excepción contemplada en el párrafo tercero del art. 4, a saber:

«Sin perjuicio de lo anterior, si cualquiera de las partes solicitase motivadamente en su escrito de calificación provisional, acusación o defensa, el conocimiento de la identidad de los testigos o peritos propuestos, cuya declaración o informe sea estimado pertinente, el Juez o Tribunal que haya de entender la causa, en el mismo auto en el que declare la pertinencia de la prueba propuesta, deberá facilitar el nombre y los apellidos de los testigos y peritos, respetando las restantes garantías reconocidas a los mismos en esta Ley.»

En suma, lo único que no cabe mantener durante las sesiones del juicio oral es el anonimato del testigo o perito, siempre que cualquiera de las partes solicitase motivadamente en su escrito de calificación provisional que se desvele la identidad de los mismos; en tal caso, será preceptivo facilitar solamente el nombre y apellidos de los mismos, pero ningún dato más (profesión, domicilio, edad, etc.). Por supuesto que el testigo o perito protegido podrá comparecer utilizando cualquier artificio que impida su identificación visual.

Para reforzar las garantías procesales previene el párrafo siguiente del art. 4 que, en el caso de que las partes hayan solicitado conocer la identidad de los testigos y peritos que hayan de comparecer en el acto del juicio oral «el plazo para la recusación de peritos a que se refiere el art. 662 de la Ley de Enjuiciamiento Criminal se computará a partir del momento en que se notifique a las partes la identidad de los mismos», añadiendo a continuación que «en los cinco días siguientes a la notificación a las partes de la identidad de los testigos, cualquiera de ellas podrá proponer nueva prueba tendente a acreditar alguna circunstancia que pueda influir 
en el valor probatorio de su testimonio»; y continúa el precepto señalado que «de igual forma las partes podrán hacer uso del derecho previsto en el apartado anterior, a la vista de las pruebas solicitadas por las otras partes y admitidas por el órgano judicial, en el plazo previsto para la interposición del recurso de reforma y apelación».

En suma, lo que la Ley pretende es que las partes puedan recusar a los peritos o suscitar cuestión sobre la credibilidad de los testigos que permanecieron anteriormente en el anonimato.

Permítasenos ahora una observación: la Ley está dando por supuesto que las partes habrán de proponer los testigos y peritos de que intenten valerse precisamente en su escrito de calificación provisional. Esto es válido en el procedimiento ordinario (art. 728 L. Crim.), pero no en el procedimiento abreviado, en el cual cabe la proposición de nueva prueba hasta el momento del inicio de las sesiones del juicio oral (art. 793-2 L. Crim.). Si sucediese esto último habría que aplicar por analogía las disposiciones contenidas en los párrafos tercero y cuarto del art. 4 para evitar indefensión, lo cual, obviamente puede conducir a un aplazamiento de las sesiones del juicio oral.

Finalmente dispone el párrafo quinto del art. 4 que:

«Las declaraciones o informes de los testigos y peritos que hayan sido objeto de protección en aplicación de esta ley durante la fase de instrucción, solamente podrán tener valor de prueba, a efectos de sentencia, si son ratificados en el acto del juicio oral en la forma prescrita en la Ley de Enjuiciamiento Criminal por quien los prestó. Si se consideraran de imposible reproducción a efectos del art. 730 de la Ley de Enjuiciamiento Criminal, habrán de ser ratificados mediante lectura literal a fin de que puedan ser sometidos a contradicción por las partes.»

Nos encontramos, sin género alguno de duda, ante el precepto que puede resultar más polémico de la Ley.

La primera cuestión que se suscita es si se ajusta al art. 24 de la Constitución Española (prohibición de indefensión; derecho a un juicio con todas las garantías) la posibilidad — admitida por la Ley- de que un testigo o perito declare en el juicio oral conociéndose exclusivamente su identidad y haciéndolo de tal modo que resulte impedida su identificación visual por las partes.

A nuestro juicio esta situación es perfectamente compatible con el régimen de garantías previsto por el texto constitucional. En efecto, téngase en cuenta que:

1. La filiación completa y las circunstancias personales del testigo o perito habrán de ser conocidas por el Juez o Tribunal sentenciador, ante el cual el testigo o perito deberán identificarse, con las 
prevenciones necesarias para que las partes sólo conozcan sus nombres y apellidos.

2. Cualquiera de las partes, acusación y defensa, pueden solicitar y es preceptivo facilitar el nombre y apellidos del testigo o perito compareciente.

3. El testigo o perito debe comparecer ante el Tribunal y declarar ante éste y las partes.

4. Las partes pueden interrogar o contrainterrogar.

5. Las partes pueden proponer prueba acerca de la credibilidad que merezca el testigo.

6. Las partes están facultadas también para intentar la tacha del perito.

Se trata, en definitiva, de un testigo o perito oculto pero no anónimo, que es oído por el Tribunal y sometido a interrogatorio contradictorio.

Recuérdese que, con arreglo a la doctrina del Tribunal Constitucional citada anteriormente, sólo el total anonimato y la imposibilidad de contradicción viciarían de anticonstitucionalidad la prueba así obtenida.

La Ley es, pues, respetuosa con los principios de oralidad, publicidad, inmediación y contradicción que rigen el juicio oral. La única limitación de facilitar sólo el nombre y apellidos del testigo o perito y permitir a éste que no se identifique visualmente, son restricciones razonables, amparadas por el principio de ponderación de bienes en conflicto, en unas causas en que el testigo o perito puede correr un grave riesgo.

Por similares razones, tampoco sería anticonstitucional que el Juez o Tribunal no facilitase la identidad de los testigos y peritos propuestos y admitidos cuando ello fuese debido a no haber mediado solicitud en tal sentido de las partes en sus escritos de calificación provisional. Lo que la Ley debe ofrecer - y ofrece- a las partes es la posibilidad de conocer la identidad de los comparecientes; si aquellas, por las razones que fuesen, no hacen uso de tal derecho, no podrán invocar luego indefensión, ya que ésta traería causa en su propia incuria.

Mucho más problemático es el párrafo último del apartado 5 del art. 4 de la Ley, en cuanto permite utilizar como prueba valorable por el Tribunal el testimonio o el informe rendido por testigo o perito anónimo en la fase de sumario que, por imposibilidad, no puede ser ratificado por su autor en el juicio oral, bastando a tal efecto su lectura literal en las sesiones del juicio.

La posibilidad de que se proceda a la lectura, a instancia de cualquiera de las partes, de las diligencias practicadas en el sumario, que, por causas independientes de la voluntad de aquéllas, no puedan ser reproducidas en el juicio oral, está expresamente admitida en el art. 730 de la Ley de Enjuiciamiento Criminal. 
Obsérvese, sin embargo, que los términos del art. 4-5 de la nueva Ley son mucho más estrictos que los del art. 730. Mientras este último se contenta con que las pruebas sumariales «no sean reproducibles por causas independientes de la voluntad de las partes», en el art. 4-5 se exige para admitir este modo excepcional de prueba que las declaraciones de los testigos o peritos sumarialmente anónimos sean de «imposible reproducción» en el juicio oral.

Por lo tanto, la primera y fundamental premisa de la que hay que partir para que pueda entrar en juego el párrafo último del art. 4 es que se trata de una imposibilidad absoluta (muerte, ignorado paradero, etc.); de tal modo que si la imposibilidad fuese relativa (inconveniente no insuperable), no será válida la reproducción por lectura. Y, aún así, habría que distinguir dos supuestos de hecho diferentes:

1. Testigo o perito anónimo en fase sumarial que no comparece en el juicio oral por imposibilidad absoluta, pero del cual las partes conocen (o pueden conocer) su identidad por haberlo solicitado, y pudo ser interrogado en el sumario por la parte a quien perjudique.

En tal caso cabe sostener, por ciertas reservas, la validez de la prueba (lectura en el juicio oral) por las siguientes razones:

a) No existiría ya en el juicio oral un testigo o perito anónimo, sino incompareciente.

b) La parte a quien perjudique tiene la posibilidad de tachar al perito, tan pronto le sea facilitada su identidad, y la de proponer prueba tendente a someter a contención la credibilidad del testigo.

c) Se respeta mínimamente el contradictorio, al haber podido interrogar al testigo o al perito durante la instrucción preliminar.

Con todo, no puede pasarse por alto el hecho de que el anonimato del testigo o perito en la fase sumarial pudo suponer una limitación al derecho de la defensa, al privar a ésta de la posibilidad de formular preguntas solamente imaginables una vez desvelada su identidad.

Por ello la prueba en estas circunstancias debe ser valorada con harta cautela por el Tribunal sentenciador; así, dicha prueba nunca debiera determinar una condena por sí sola y solamente sería admisible su toma en consideración dentro de un conjunto de pruebas o indicios que apuntasen en la misma dirección.

2. Mismo caso que el anterior, con la diferencia de que el perito o testigo anónimo no pudo ser interrogado en la fase sumarial por la parte a quien perjudique. 
En este supuesto somos de la opinión de que no cabría la lectura literal del testimonio o peritaje para otorgar el valor de prueba, ya que faltaría el mínimo de contradictorio y se colocaría a la defensa en clara desventaja, violando el derecho a un proceso con todas las garantías.

Téngase en cuenta que si ya la Ley establece un régimen excepcional, tal excepcionalidad dentro de lo excepcional debe ser interpretada con carácter restrictivo.

\section{Recapitulación final}

La promulgación de una Ley de Protección de Testigos y Peritos en causas criminales era necesaria por tres razones:

1. ${ }^{\circ}$ Porque no cabe exigir comportamientos heroicos a los ciudadanos.

2..$^{\circ}$ Porque la sociedad no puede quedar indefensa frente a las manifestaciones más graves de la delincuencia, y

3. ${ }^{\circ}$ Porque era preciso fijar nítidamente la frontera entre lo permitido y lo prohibido en materia de garantías cívicas y del justiciable.

La nueva Ley carece de precedentes en el Ordenamiento Jurídico de nuestro país. Se trata, por lo tanto, de un punto de partida, no de una meta definitiva. La experiencia y la praxis diaria aconsejarán retoques para ajustar el mecanismo jurídico a la realidad de la vida y a los dictados tanto del Tribunal Constitucional como del Tribunal Europeo de Derechos Humanos.

La Ley objeto de comentario pretende armonizar los derechos en conflicto, pero en todo caso es preciso tener bien presente que se trata de una normativa excepcional, que sólo debe entrar en juego tras una seria ponderación de los bienes jurídicos enfrentados. Una vez más cobra vida la frase de Carnelutti: «Conciliar lo inconciliable; esa es la gran tragedia del Derecho.»

La Ley recién nacida evidentemente no es una panacea, pero sí un paso hacia delante. No es el bálsamo de Fierabrás para los testigos y peritos inquietados por la sencilla razón de que la máxima protección que cabría brindarles, el anonimato, habrá de romperse en el juicio oral si cualquiera de las partes lo solicita; lo cual suscitará justificadas reticencias en aquellos que potencialmente estarían dispuestos a brindar su colaboración a la Administración de Justicia. Pero justo es reconocer que supone un progreso, en la medida en que, si bien la protección que se acaba de senalar no puede ser garantizada al testigo o perito renuente, no lo es me- 
nos que, con el nuevo instrumento legal, podrá gozar de una serie de medidas protectoras hasta ahora desconocidas.

Quedan extramuros de la Ley materias tan importantes como son el Estatuto Jurídico del «agente infiltrado», del «arrepentido» y de la protección y asistencia a la víctima del delito, temas necesitados de una pronta regulación ${ }^{16}$.

Y para concluir, formulemos un deseo: que la nueva Ley, el buen criterio de los Jueces y la valentía cívica se aúnen para hacer frente a las formas más graves de aparición de la delincuencia.

16 Palacio SÁnchez-IzQuierdo, José RicARdo. «La asistencia a las víctimas del delito en Vizcaya». Eguzkilore. Cuaderno del Instituto Vasco de Criminología. n. ${ }^{\circ}$ 6, 1992, pp. 153 y ss. 